\title{
China’s Financial Linkages with Asia and the Global Financial Crisis
}

First draft: November 21, 2012

Revised draft: March 1, 2013

Reuven Glick

Economic Research Department

Federal Reserve Bank of San Francisco

reuven.glick@sf.frb.org
Michael Hutchison

Department of Economics

University of California, Santa Cruz

hutch@ucsc.edu

\begin{abstract}
:
This paper presents empirical evidence on asset market linkages between China and Asia and how these linkages have shifted during and after the global financial crisis. We find only weak cross-country linkages in longer-term interest rates, but much stronger linkages in equity markets. Moreover, we find that the strength of the correlation of equity prices changes between China and other Asia countries increased markedly during the global financial crisis and has remained high in recent years. These results are consistent with greater development and liberalization of equity markets relative to bond markets in China, as well as increasing business and trade linkages in the region.
\end{abstract}

An earlier draft of this paper was presented at the JIMF-NIPFP-DEA Conference held on December 12-13, 2012 in Neemrana Fort Palace, Rajasthan. We thank Rajeswari Sengpupta and conference participants for helpful comments and Jeremy Pearce for research assistance. The views expressed below do not represent those of the Federal Reserve Bank of San Francisco or the Board of Governors of the Federal Reserve System. 


\section{Introduction}

China's pace of real growth and transformation into a global economic power over the past three decades has been unprecedented. However, the development of its financial sector has been more gradual and irregular. Despite evident growth in the size and depth of China’s financial sector, state-controlled banks and institutions dominate financial markets, many asset prices are heavily managed, and a myriad of regulations and controls still affect international financial transactions. This uneven pattern of development raises the question of how soon will the ongoing liberalization of China’s financial sector and the “internationalization” of its currency, the renminbi (rmb), enable China financial sector to catch up with the real side of the economy, allowing China to stand among other major economic powers as a world financial center.

A large body of literature has addressed various aspects of the policy challenges faced by China as it seeks to sequence capital-account opening and currency internationalization with other policies, such as exchange-rate flexibility and financial market development (e.g. Glick and Hutchison, 2009). Less well discussed is how the global financial crisis (GFC), together with the gradual process of China's domestic financial development and drive toward internationalization of the rmb has affected its Asian neighbors. Given the size and dynamism of China's economy, these forces inevitably will have repercussions, not only for the global financial system, but for its regional trade and financial partners in Asia as well. Moreover, these connections may have deepened with the advent and aftermath of the GFC that pushed China even further to the fore of the world economy as an engine of growth.

The impact of China's economic development on global trade and production connections is self-evident and well documented by business and economic research. Less 
studied has been the extent to which impulses from the Chinese economy have been transmitted to financial markets abroad?

These linkages may be both real and financial in nature. On the real side, trade linkages_-working through final goods or input markets-- may link economies' financial sectors via the transmission of business cycle fluctuations, even without direct connections and arbitrage across financial markets. On the financial side, the increased size and depth of Chinese financial markets, combined with domestic financial liberalization and the limited deregulation of international capital flows to date, may also foster stronger financial sector linkages. Moreover, stronger financial linkages may have been created with the onset of the global financial crisis (GFC), which disrupted traditional international financial linkages, challenged the dominant position of the United States in global financial markets, and correspondingly boosted the role of China both as a destination and source of financial capital. Thus, the "attentiveness" of international investors to financial developments in China, particularly investors in other Asian equity markets in Asia, may have increased since the GFC.

In this paper we investigate the extent of Chinese financial linkages with its East Asian neighbors, how these connections have been affected by the GFC, and how the financial role of China has shifted in relation to the United States. We examine linkages in equity and bond markets, both of which depend in principle upon the extent of trade linkages, the size, depth, and liberalization of domestic financial markets, as well as on the degree of capital account openness. We investigate both equity and bond prices, since the China has liberalized its domestic equity markets and outward foreign direct investment --linking Chinese economic development to equity markets abroad-- much more than it has liberalized its bond markets. The differential “interconnectedness” between equity and bond markets in China with those in other East Asian 
economies, in turn, may shed light on the effects of financial deepening and liberalization in equity markets as opposed to linkages related to common business cycles and trade linkages. We find that equity market linkages between China and other Asian countries have grown substantially since the GFC, while bond market linkages are limited and fairly stable. Our review of the literature and own empirical analysis suggests that the rise in equity market linkages is not attributable to greater domestic financial market deepening or liberalization of international capital flows, since no major changes in these areas occurred around the time of the GFC. We argue instead that the GFC caused disruptions in traditional financial linkages and increased investors" awareness of China and "attentiveness" to its role as an origin and destination of equity finance, partly because of substantial trade linkages, foreign direct investment flows, and the interconnections of business relationships. Theory and empirical evidence suggest that once investor "inattentiveness" turns to "attentiveness," the stronger financial linkages that ensue are likely to endure (Mondria, Wu, and Zhang, 2010; Mondria and $\mathrm{Wu}, 2011)$. This is a plausible explanation for the substantial and persistent rise in equity market linkages between China and Asia since the GFC.

The next section discusses the major forces that are likely to influence financial market linkages between China and Asia. These include the size, depth, and liberalization of China's domestic financial markets, as well as the liberalization of international capital controls and internationalization of the rmb. The third section discusses the extant literature on financial linkages in Asia. The fourth section presents our empirical analysis. The fifth section concludes. 


\section{Financial deepening and liberalization in China}

\subsection{Equity and bond markets in China}

China's system of formal finance is "bank centered” and primarily dominated by four large state-owned banks. The ratio of bank credit to GDP in the PRC, 1.27, is much higher than even than that in the German bank-centered system of finance, .99. Securities markets play a much smaller role than does bank finance, partly because equity and bond markets are both dominated by government issuance and state-owned enterprises (SOEs), and partly because the shares that trade on the exchanges are a small percent of the outstanding shares (Allen and Shen, 2011; Fungáčová and Korhonen, 2011).

The government established new and tightly controlled stock exchanges in the early 1990s in Shanghai and Shenzhen, designed primarily to help in the financing of state-owned enterprises. Since that time these exchanges have developed rapidly in terms of listings, trading, products, and regulatory structure. Nonetheless, access to equity markets in China has been tightly controlled by the state and these markets largely have played the role of a supplemental source of finance for large state-owned enterprises.

The bond market in China is also relatively undeveloped and dominated by government issuers. Total local currency bonds outstanding China amounted to \$3.5 trillion at end-June 2012 (Asian Development Bank, 2012), of which \$2.6 trillion were Treasury bonds (74 percent of total), primarily issued by the Ministry of Finance (\$1.2 trillion) or policy banks (e.g. China Development Bank, Export-Import Bank, and Agricultural Development Bank of China). Bond trading is limited, as most bonds are held by banks (68 percent of Treasury bonds at end-June 2012). Private bond market capitalization remains a small fraction of the total and, moreover, is dominated by state-owned companies. Of the current top 50 corporate bond issuers in China, 
accounting for 65 percent of all outstanding corporate bonds, 42 are state-owned (Asian

Development Bank, 2012).

\subsection{Internationalization and liberalization}

“Internationalization” of a currency generally involves permitting its use by domestic and foreign agents in international trade and financial transactions both inside and outside of a country’s borders. Greater internationalization of the renminbi, in turn, should be accompanied by tighter financial linkages between China and its neighboring economies. Full internationalization of the renminbi (rmb) is a tall order for a country that currently maintains numerous financial controls and heavily regulates domestic and cross-border financial transactions. Nonetheless, Chinese leaders have made concerted efforts to encourage greater international use of the rmb since the G-20 summit in November 2008 when Chinese President Hu Jintao called for "a new international financial order that is fair, just, inclusive, and orderly," and China subsequently began to encourage more use of its currency in international trade, swap arrangements between central banks, and bank deposits and bond issuances in Hong Kong. ${ }^{1}$

It is evident that China has pursued a cautious path towards greater financial liberalization and openness, and has only just begun the process of allowing residents and nonresidents alike to use the currency to trade, invest, borrow, and invoice outside of China (McCauley, 2011; Prasad and Ye, 2012). Evidence of measures to increase financial integration include the greater use of the rmb in the denomination and settlement of cross-border trade and

\footnotetext{
${ }^{1}$ According to Mallaby and Wethington (2012), during the first six months of 2011, trade transactions settled in rmb totaled around \$146 billion, a 13-fold increase over the same period during the previous year. By mid-2011, rmb deposits in Hong Kong equaled \$85 billion, a roughly tenfold jump since Hu's 2008 statement. The yuan is already accepted as a form of payment in Mongolia, Pakistan, Thailand, and Vietnam. Chinese authorities have indicated that as soon as 2015, they want the yuan to be included in the basket of major currencies that determines the value of Special Drawing Rights.
} 
financial transactions, expanding trade settlement in Hong Kong, and rising issuance of renminbi-denominated bonds both in Hong Kong and the Mainland (Prasad and Ye, 2012).

Although tax benefits and other incentives have been used to promote inward foreign direct investment, other forms of inflows, particularly portfolio capital and external debt, have been traditionally discouraged. Capital controls have also played a role in protecting the banking system from external competition by restricting the entry of foreign banks and by making it harder for capital to flow out of the country. Since the start of China's reform and open-door policies, foreign direct investment (FDI) inflows have been encouraged, while other inflows and capital outflows were initially heavily controlled. ${ }^{2}$ Non-bank Chinese residents and institutions had been prohibited from directly investing in overseas securities, though banks were permitted to invest their own dollar assets in fixed income instruments

In recent years, China has liberalized controls on non-FDI capital flows very slowly. Authorized banks were allowed to transact cross-border to accommodate onshore non-bank depositors and borrowers wishing to deposit and borrow in foreign currency. China has sought to institutionalize the management of two-way portfolio flows through programs for so-called "qualified foreign institutional investors" (QFIIs) for portfolio inflows and "qualified domestic institutional investors” (QDIIs) for portfolio outflows. ${ }^{3}$ Both programs involve pre-approval procedures, quota management, foreign exchange conversion rules, instrument restrictions, and

\footnotetext{
${ }^{2}$ The rmb has been convertible for current account transactions since December 1996, when China satisfied the IMF's Article VIII criteria for membership.

${ }^{3}$ In December 2002, QFIIs were allowed to invest in A shares and other domestic securities, subject to requirements of at least $\$ 10$ billion in assets under management and prior experience. Repatriation was limited by lock-up periods on stocks of as long as one-year. New rules in September 2006 lowered the asset under management criteria to \$5 billion, reduced the lock-up period to three months, lessened experience requirements, and also raised the quotas for investment in Chinese equities. The QDII program, launched in July 2006, permitted qualified commercial banks, securities firms, and insurance companies in China to make limited offshore investments in foreign-currency denominated assets (restricted to fixed income securities in the case of banks and insurance companies). More recently, in response to concerns about increased capital outflows as the economy has slowed, China has accelerated its approval process to allow more capital inflows into its stock and bond markets via the QFII program.
} 
intensive reporting requirements. With the introduction of the QDII plan in 2006, China opened an official channel for Chinese households and firms to gain access to global financial markets. Appreciation pressures on the rmb have led China to encourage outflows through other channels, for example, by relaxing restrictions on currency conversion by domestic residents. ${ }^{4}$ In addition, firms and banks have been given flexibility to issue foreign-exchange denominated bonds in local markets and to raise their direct overseas investment.

Though China had tightly controlled portfolio flows and most external debts for a long time, there is evidence that these capital controls were leaky and had tended to become less effective over time even before the recent relaxation of capital controls. ${ }^{5}$ The sheer magnitude of net and gross portfolio capital and "hot money" inflows clearly casts doubt on the effectiveness of China's capital control regime. Moreover, as the evidence presented in Glick and Hutchison (2009) and Ma and McCauley (2007) illustrate, despite the existence of remaining capital controls, there are many indications that China's capital account flows respond to market conditions, suggesting limits to the effectiveness of these controls. "Hot money" flows have apparently been responsive to expectations of rmb appreciation. Similarly, foreign exchange deposits held by Chinese households and firms onshore with banks in China have tracked exchange rate expectations, rising as a share of total bank deposits when the rmb was expected to depreciate and falling when the rmb was expected to appreciate.

Permitted cross-border flows have likely reduced the effectiveness of China’s remaining capital controls, but they have not been large enough to eliminate onshore/offshore rmb yield

\footnotetext{
${ }^{4}$ In 2007 the PBOC raised to $\$ 50$ thousand the ceiling on the conversion between rmb and foreign currency by Chinese individuals.

${ }^{5}$ Prasad and Wei (2007) provide an extensive chronology of capital controls over the period 1980 - January 2005; Prasad and Ye (2012) update the chronology to 2011. They document the increasing openness of China's capital account in both de jure and de facto terms through selective and cautious changes, consistent with the active promotion of the rmb as an international currency. However, in most cases, they argue that constraints on capital inflows and outflows have been merely relaxed rather than eliminated entirely.
} 
differences. For example, the Chinese government in 2011 successfully issued rmb-denominated bonds in Hong Kong at rates lower than those offered onshore. The differential in the prices of Chinese equities between the mainland and Hong Kong also points to the effectiveness of capital controls. And limited integration between China's domestic and international interbank markets is also evident (Hutchison, Pasricha, and Singh, 2012). Clearly, Chinese capital controls have been effective in partly “decoupling” Chinese financial markets from those in the U.S., Hong Kong, and elsewhere (see Cheung et al., 2005; Ma and McCauley, 2007; and Otani, Fukomoto, and Tsuyaguchi, 2011; Lee, Huh, and Donghyun 2011, McCauley, 2011; Prasad and Ye, 2012).

In sum, there have been some development and liberalization in Chinese financial markets, more so in equities than bonds. And a greater part of the permitted internationalization process in China, presumably leading to greater financial linkages abroad, has focused on equity markets and FDI flows, as opposed to debt instruments.

\section{Empirical literature on China's financial linkages with East Asia}

China's growing role in global trade and financial markets has affected its East Asian regional neighbors. Given the size and dynamism of China’s economy, greater financial openness and internationalization of the rmb has repercussions for the global economy, and even more so for its regional trade and financial partners in East Asia. Several studies have investigated how these developments have affected asset price linkages in the region.

Cheung et al. (2008) examine the interactions between the Chinese and U.S. interest rates and finds that the U.S. effect on Chinese interest rates is quite weak. Apparently, even with its de facto peg to the U.S. dollar, China has measures in place that have enabled it to retain its policy independence and de-link its interest rates from U.S. rates. 
Jang (2011) analyzes the degree of financial integration of China, Japan, Korea, and the United States by examining correlations of bond market rates and stock market changes using data from the early or mid-1990s through mid-2010. He finds that the correlations of monthly Asian money market rates with United States rates increased after the Asian financial crisis, though China's correlation is the lowest in the group. Correspondingly, the correlation of money rates of Japan and Korea with that of China, which was negative before the Asian financial crisis, turned positive after the crisis, as rates in the region have moved more closely with each other in recent years. He also finds that the correlations of Japan and Korean government bond rates also increased with U.S. rates after the Asian financial crisis. China's bond rate (with data available only since 2005) does not show a significant correlation with the United States after the crisis, though it does display positive correlations with Japan and Korea, particularly with the latter.

Liu et al. (2013) analyze real interest rate linkages and find evidence that real interest parity (RIRP) holds for ten East Asian countries, and that these countries are highly influenced by external factors originating from China. They also find that real interest rate differences with China mean revert toward equilibrium in a non-linear way. Baharumshah et al. (2011) analyze financial linkages between the United States and East Asian economies, testing for real interest rate parity using long-run panel techniques. They find evidence that the parity condition holds in all the Asian countries, arguing that failure to account for structural breaks in the industrialized countries and Asian emerging economies is responsible for the rejection of RIRP in earlier studies.

Huyghebaert et al. (2010) examine the integration and causality of interdependencies among stock markets in seven major East Asian countries before, during, and after the 19971998 Asian financial crisis using daily data. They find that the relationships among East Asian 
stock markets are time varying. While stock market interactions are limited before the Asian financial crisis, they find stronger linkages in most East Asian markets, including Shanghai and Shenzhen, during the crisis. Jang (2011) also considers linkages among stock markets. He finds that stock markets in Japan, Korea, and China move more tightly with the U.S. stock market, though less so for China, after the Asian financial crisis and also show positive correlations among themselves. The correlations in stock price indices in other East Asian countries also suggest a tighter interrelationship with the U.S. stock market following the Asian financial crisis. The relatively low correlations of U.S. and Chinese asset price changes in recent years are consistent with their differences in economic recovery rates and inflation concerns. ${ }^{6} \mathrm{Jang}$ concludes that in the last decade Asian countries have achieved remarkable progress in economic integration. However, the degree of integration financial integration lags significantly behind the degree of trade and real economy integration. ${ }^{7}$

Li (2012) investigates the more specific question of how China's stock market reforms have affected stock market linkages between China and Korea, Japan, and the United States, respectively. He examines China's regional and global linkages between 1992 and 2010 and during three sub-periods corresponding to different phases of Chinese financial reforms, finding that Chinese reforms have resulted in greater spillovers to Korea and Japan. He finds, however, that the correlation between China's equity market and the U.S. market remains weak.

A number of papers focus on co-movements of exchange rates in the region. For example, Balasubramaniam, Patnaik, and Shah (2011), following the methodology of Frankel

\footnotetext{
${ }^{6} \mathrm{He}$ also examines deviations from uncovered interest parity, with the expected exchange rate change used in these calculations proxied by the previous period's actual change. For a related exercise analyzing real interest linkages among Pacific Basin countries, see Glick and Hutchison (1990).

${ }^{7}$ Quantity-based measures include measurement of openness and restrictiveness in trade and financial transactions, cross-border movement of capital, output and consumption correlations, and savings-investment correlations. They yield similar conclusions; see Jang (2011).
} 
and Wei (1994) and Frankel (2009), estimate the effects of changes in the dollar, euro, yen, and rmb on individual East Asian currencies over the period October 2005 to February 2011, using the Swiss Franc as the numeraire. They find that the effect of the rmb is significant only for Malaysia (from 2005 to 2007), Viet Nam (after 2009) and Taiwan (through the entire sample). ${ }^{8}$ These results suggest that while China has made strides in terms of achieving a major role for the rmb in international trade through the establishment of rmb settlement mechanisms and swap lines, there is relatively limited evidence of an independent effect of the rmb on the exchange rate policies of neighboring economies. ${ }^{9}$

Our review of the literature suggests mixed evidence for China concerning both the pace and implications of its domestic financial development and liberalization. Some authors have found that China’s financial markets have become more integrated with its Asian neighbors despite limited domestic financial liberalization and pervasive capital controls, due to growing trade and business linkages. Others argue that China's financial role in Asia is minimal and does not approach its role in regional trade and its importance as a regional source of economic growth. This suggests that additional analysis of the extent of financial integration within Asia is warranted.

\section{Empirical analysis of China and Asian financial linkages}

In this section we analyze the extent of China's asset market linkages with its Asian neighbors and how they have changed over time. We also investigate how global financial

\footnotetext{
${ }^{8}$ Somewhat ironically they find that the rmb mattered more outside of East Asia, including India and Pakistan, as well as many countries in Africa.

${ }^{9}$ Ma and McCauley (2010) argue that it is important to consider the frequency of the data when analyzing correlations. For example they find that the co-movement of the renminbi with major currencies other than the dollar is greater at lower frequency, i.e. at weekly or monthly intervals rather than at a daily frequency.
} 
factors and national financial turbulence, particularly during the recent global financial crisis (GFC), may have influenced the extent to which interest rate and equity price changes have been transmitted from China across Asia. Evidence of linkages in bond rates would indicate that China has a significant effect on corporate and government costs of finance in other countries. Linkages among equity prices could reflect either financial ties through international portfolio management and capital flows and/or trade linkages through product competition and export and import flows.

More specifically, we analyze linkages of government bond interest rates and equity prices — between China and eight large Asian countries—Indonesia, Korea, Malaysia, Philippines, Singapore, Taiwan, Thailand, and India—using daily data on closing 5-year bond rates and equity prices obtained from Bloomberg. ${ }^{10}$ Our full sample period extends from June 2, 2005, when the daily asset price data for China are available, through October 24, 2012. We also consider three sub-periods corresponding to (1) the "tranquil” period before the GFC, June 2005 - June 2008; (2) the GFC period, July 2008 - May 2010; and (3) the post-GFC period, June 2010 - October 2012. ${ }^{11}$

\subsection{Plots and correlations}

Figure 1 plots bond rates for the Asian countries in our sample as well as the United States. Observe that U.S. and China bond rates appear largely decoupled, sometimes moving together, but frequently moving in opposite directions. With the exception of a rise at the peak of the financial crisis in late 2008, bond markets elsewhere in Asia countries do not appear tightly

\footnotetext{
${ }^{10}$ The equity price data for China is from the Shanghai stock market.

${ }^{11}$ The specific subperiod ranges are June 2, 2005 to July 9, 2008, July 10, 2008 to June 20, 2010, and June 21, 2010 - October 24, 2012, respectively. The GFC period roughly corresponds to the time span over which China responded to the crisis by halting the appreciation of the rmb against the U.S. dollar that it first began in July 2005.
} 
linked with China, apparently moving in response to domestic inflation and other domestic macroeconomic conditions.

Figure 2 presents analogous plots of equity prices. Similar to the case for bond rates, the figure suggests very little co-variation between U.S. and China equity prices except for the sharp decline at the beginning of the GFC in late 2008, while in the post-GFC period U.S. equities rose very gradually, with Chinese equities rebounding more rapidly. The figure also indicates a pattern linking China with other Asia countries not only during the GFC, but in the period after as well. In particular, the worldwide drop in equity markets affected other Asia countries simultaneously during the GFC period, but in the post-GFC period there was a wide-spread robust upturn in Asia equity markets, suggesting a greater coupling of equity prices in China and other Asian economies.

We confirm these visual impressions with simple correlations of daily changes in Chinese and Asian country bond rates (first differences in percentage points) and equity prices (first differences in logs) for the full sample period and our three sub-samples. ${ }^{12}{ }^{13}$ Correlations of Asian bond rates and equity price changes with the U.S. are also presented for comparison. U.S. market changes are lagged one day to account for timing differences in market opening and closing across time zones since Asian markets are closed by the time that U.S. markets open on any given day.

The correlation results reported in Table 1 yield several insights. First, the cross-country correlations of bond and equity return changes, with rare exceptions, are positive. Among the exceptions, the bond rates of Indonesia and the Philippines are negatively correlated with the

\footnotetext{
${ }^{12}$ In the case of weekends, U.S. holidays falling in mid-week, or other days with missing data, changes are calculated using the closing price of the nearest prior trading day, as long as it is no more than three days earlier.

${ }^{13}$ In the following section we present unit root tests that indicate the need to first difference asset returns in order to render them stationary.
} 
United States because of rising risk premia in these countries during the GFC, while bond rates in the United States were falling.

Second, the equity return correlations with both the United States and China are much higher than the bond correlations. For the full sample, equity return correlations with the U.S. are roughly .40 or higher, while the highest bond rate correlation is .29 (for Singapore). Equity return correlations with China are .20 or higher, while the bond return correlations are all less than .10. This suggests stronger cross-country linkages across equity markets than across government bond markets.

Third, equity and bond changes in Asia are generally more correlated with the United States than with China, with the exceptions again of the bond rates for Indonesia and the Philippines as well equity returns in India. In fact, the bond correlations with China in particular are generally quite low and insignificant for most countries, suggesting limited arbitrage in debt markets between China and other Asian bond markets.

Fourth, the correlations of China and the United States with each other are lower than their respective correlations with Asian countries. For example, the U.S.-China correlation over the full sample for equity prices is .17, while that for bond rates is virtually zero. This suggests that bond rate changes in China and the United States, and to some extent equity return changes as well, can be regarded as independent shocks for other Asian countries.

Fifth, equity correlations with the U.S. equity market are quite high in all periods, though they declined marginally during the GFC period.

Finally, there is a perceptible shift in the cross-country equity correlations with China, which were relatively low in the pre-crisis period, but rose markedly during the crisis. These correlations ranged from .09 in Thailand to .27 in Singapore in the pre-GFC period, but rose 
above roughly .30 in all countries during the GFC. This is consistent with the GFC acting as a common financial shock which was transmitted globally. Moreover, the high equity correlations of the GFC period continued into the post-GFC crisis period (mid 2010 to late 2012), indicating the newfound importance of China's equity markets may be a permanent institutional feature in equity pricing in other Asian financial markets.

Figures 3 and 4 illustrate the last two points with bar charts by showing the correlations of equity returns for China and the U.S., respectively, with the eight Asian countries in our sample over the three sub-periods. The sharp rise in correlations between China and the Asian region across the three sub-periods is clearly evident in Figure 3. The average correlation is .20 in the pre-GFC sample, and .35 in the post-GFC sample. By contrast, consistently high correlations across U.S. and Asian equity markets are observed in Figure 4, with a slight decrease during the GFC.

\subsection{Benchmark regression analysis}

We continue our analysis with multivariate regression equation results. We focus first on estimating the effects of China asset rate changes on Asian financial markets, while controlling for the common shock of U.S. asset return changes. We subsequently augment our analysis to control for other determinants of asset price changes, such global and national risk shocks.

The purpose of this analysis is to investigate two basic issues more formally: First, to what extent do China's asset returns affect returns in other Asian countries, after controlling for country-risk factors and common shocks (e.g. U.S. financial market movements and global risk)? And, second, given that the global financial crisis significantly affected global capital flows, did it also affect the depth and intensity of financial linkages between China and other Asian countries? 
As in our correlation analysis, bond rates are expressed as first differences of the daily rate levels, while equity returns are expressed as logged first differences of daily price levels, with U.S. data lagged by one day to account for timing differences in market opening and closing across time zones. ${ }^{14}$ Table 2 shows results for bivariate regressions for our eight Asian countries involving only the U.S. and China asset returns as explanatory variables as well as multivariate regressions with both included for the full sample period. The regressions all include unreported constant coefficients. The pooled coefficients reported in the last column of the table employ a fixed effect estimator, with errors clustered by country.

The bivariate results confirm insights from the simple correlations discussed in the previous section: (1) the coefficients for the effects of U.S. bond rates are positive, larger, and more significant than those for China bond rates, with the exception of Indonesia and the Philippines which are negative and significant ${ }^{15}$, (2) the coefficients for the effects of equity returns are all strongly significant for both countries, though the magnitudes of the coefficients for U.S. returns are larger than those for Chinese equity returns, and (3) the equity return coefficients with both the United States and China are much higher than the bond correlations,

\footnotetext{
${ }^{14}$ In preliminary analysis, we conducted augmented Dickey-Fuller unit root tests and concluded that first differences in asset prices were stationary. As reported in Appendix Table A1, unit roots cannot be rejected for either the levels of bond rates or (the log of) equity price indices. First differencing, however, is found to render the series stationary. We also conducted Granger causality tests for each country with both the U.S. and China in 3 variables systems. As reported in Appendix Table A2, U.S. bond rates granger cause rates in China and almost all other Asian countries at a better than .05 significance (the exceptions are Indonesia bond rates with a p value of .66 and the Philippines with a p value of .10), while U.S. equity returns granger cause returns in all Asian countries, including China, at better than .05. In contrast, China bond rates do not granger cause any other Asia countries at .05, while China equity returns granger cause returns in only two Asian countries (Malaysia and India) at this significance level. More importantly, other Asian countries do not granger cause U.S. or Chinese bond and equity rates (with the anomalous exception of the effect of Indonesia bonds on U.S bond rates). This confirms our presumption that U.S. and China asset prices may be interpreted as exogenous to other Asia rates and obviates concerns about possible reverse causality from the dependent variables in the regressions we estimate. The results we report below are not affected by including lags of the dependent or explanatory variables. Results with lags are omitted for brevity, but are available upon request.

${ }^{15}$ Note, however, that the negative association of bond rates in these countries with the U.S. is strong enough to yield a pooled effect for the U.S. that is lower than that of China.
} 
suggesting stronger cross-country linkages across equity markets than across government bond markets.

Lastly, we note that the coefficients in the multivariate regressions with both U.S. and China returns included together are little changed from those in the bivariate regressions. This is consistent with our earlier observation that U.S. and China returns exhibit limited correlation with each other. Focusing on the pooled results in the last column of Table 2 with both the U.S. and China equity returns entering simultaneously, a 1 percent increase in U.S. and China equity returns is associated with an increase of .33 percent and .16 percent, respectively, in other Asia countries.

We next augment the regressions to control for global and country-specific risk. Global risk in the context is proxied by the VIX rate, measuring the implied volatility of S\&P 500 index options., and, country-specific risk is proxied by the credit default swap (CDS) rate on national sovereign debt for those countries where this variable is available (data is unavailable for Singapore, Taiwan, and India). We consider other possible determinants, such as oil prices, exchange rate policy, and capital controls in robustness exercises presented in the following section.

Figures 5 and 6 show the movements of the VIX rate (basis points) and country-specific sovereign CDS spreads (basis points), respectively, for the five Asia countries in our sample for which data are available. It is evident that VIX and CDS spreads moved closely during the GFC but in other periods there is considerable "decoupling," indicating that idiosyncratic country-risk characteristics are important. 
Table 3 shows the results of augmenting the bond rate and equity return regressions with VIX and CDS variables expressed as percent changes for the full sample period. ${ }^{16}$ The table indicates that the VIX rate is positively associated with bond rates and negatively associated with equity returns, as expected. Likewise, CDS rates have a positive (though only marginal) effect on bond rates and a strongly negative effect on equity returns. A comparison of coefficients for those countries with CDS data indicates that CDS spreads have a more pronounced effect than the VIX on asset returns in Asian countries.

Observe also that the Chinese bond rate coefficients are statistically significant only for Indonesia and Korea, while the U.S. rate coefficients are significant for all countries, except for Indonesia and the Philippines, which are insignificant. Evidently, controlling for risk eliminates the strong negative association between the bond rates of these countries with the United States reported in Table 5. The pooled results indicate that after controlling for risk that the effects of U.S. and Chinese bond rates on Asian bonds are comparably low (i.e. .09 for both countries in the specification with VIX). Moreover, when the CDS rate is added, the coefficient for China, .12 , actually exceeds that for U.S., .08, though this result can be attributed to the dropping from the sample of Singapore, Taiwan, and India - countries with a low sensitivity to China rates because of their lack of data on CDS rates.

The augmented equity return regressions in Table 3 are also consistent with earlier results in finding a large and robust association of Chinese equity price changes with other Asian countries. U.S. equity returns are also significant in almost all cases and, though still higher in magnitude than the corresponding China effect (with the exception of India), the differences in magnitude are somewhat smaller after controlling for risk considerations. Focusing on the pooled results in the last column of Table 3 with the VIX rate (but without the CDS rate),observe that a

\footnotetext{
${ }^{16}$ Appendix Tables 3 and 4 report results with the VIX by subperiods.
} 
1 percent increase in U.S. and China equity returns is associated with an increase of .24 percent and .16 percent, respectively, in other Asia countries

How has the strength of transmission/linkages changed with the advent of the GFC? Our earlier analysis suggested changes in correlation of asset prices over time. To answer this question Table 4 reports pooled regression results in which we interact U.S. and China asset returns with time dummies for the GFC and post GFC time periods (DGFC and DpostGFC, respectively). With this specification, the coefficients on the U.S. and China asset change variables reflect the effects during the pre GFC period, while the coefficients on the interaction terms capture the possible shifts in this effect over time.

Observe first from column (1) in Table 4 that there is evidence during the GFC of a decline in the sensitivity to U.S. bond rates and an increase in the sensitivity to China bond rates, but these effects are insignificant. In contrast, we do observe a significant decline in the sensitivity to U.S. equity returns in the GFC and post-GFC periods and corresponding increases in the sensitivity to China equity returns.

These results also confirm our earlier findings that the transmission of Chinese equity rates rose markedly during the GFC and has remained high through the end of the sample, while no significant shift occurred for bond interest rate transmission. In particular, the coefficient for transmission of U.S. interest rates (0.11) in Asia in the pre-GFC period remains larger than that for China (0.03), with no discernible shifts associated with the GFC. In contrast, the coefficient on Chinese equity returns is much smaller during the pre-GFC period (.09) compared with that for the U.S. (0.51), but rises substantially during the GFC (by 0.16) and post-GFC (by 0.14). The transmission of U.S. equity price changes correspondingly declined during the GFC (by 0.29) and post-GFC (by 0.26). 
At present, the transmission of equity prices across Asia is very similar for the U.S. and China, a remarkable shift in relative financial market importance from just a few years ago. Thus while a 1 percent increase in U.S. equity returns was associated with a .51 percent increase in Asian equity returns in the pre-GFC period, this effect fell to only a $.25(=0.51-.26)$ percent increase in the post-GFC period. Correspondingly, the effect of a one percent increase in China equity returns on other Asia country returns rose from .16 in the pre-GFC to $0.23(=0.09+0.14)$ percent in the post-GFC period. Thus in the post-GFC period the transmission effects of equity price changes from the U.S. and China to Asia were about equal.

The table also reports in column (2) evidence of a significantly more negative response of bond rates to the VIX and a corresponding increase in the response of equity returns in the postGFC period. Perhaps surprisingly, there is no evidence of any significant change during the GFC period.

\subsection{Other sources of transmission: oil, Chinese monetary policy and global uncertainty}

In this section we consider other possible determinants of Asian asset returns, such as oil prices, an alternative measure of China financial market changes, and possible interaction with risk. Tables 5 and 6 report the results of these regressions for bond rate and equity returns, respectively, using a pooled fixed effect regression estimator for the full sample that extends our "baseline" (shown in column (1) for both bond and equities in Table 4) to include these additional explanatory variables.

As indicated in column (1) of these tables, oil price changes do not significantly affect either bond or equity prices. We next consider an alternative measure of Chinese financial shocks that may be interpreted as more exogenous to other Asian countries — changes in Chinese monetary policy as captured by reserve requirement changes. Column (2) of Tables 5 and 6 
shows the response of Asian bond and equity prices, respectively, to dummy variables for the days of increases (China RR incr) and decreases (China RR decr) in reserve requirements on banks set by the People’s Bank of China (PBOC), one of its operating instruments of monetary policy. ${ }^{17}$ The expected effect of these announcements is unclear. On the one hand, we would expect loosening (tightening) of monetary policy and credit in China, captured by decreases (increases) in reserve requirements, to strengthen (weaken) equity prices elsewhere in Asia. On the other hand, the announcements of loosening may also have a signaling effect of how weak is the Chinese economy, implying a negative effect on other its trading partners. In fact, we do find evidence that China's reserve rate increases had a negative and significant effect on equity prices. The effects on bond rates are insignificant, however.

Column (3) of Tables 5 and 6 report the results of introducing interaction terms involving VIX with China and U.S. asset rates. This allows us to test whether the strength of transmission of foreign asset changes across Asia is influenced by global risk. In the case of bond rates (Table 5), we do not find evidence that the strength of the transmission is affected by global risk. That is, the interactive effects between China bond rate changes and the VIX are insignificant. In the case of equity returns (Table 6), however, the interactive terms for both China and U.S. equity returns are positive and significant. Thus, higher global risk is associated with a greater response by Asian equity returns to developments in China and U.S. equity markets.

An important common result spanning all of these additional regressions is that the main results from the baseline regressions are robust. That is, there is a marked discrete shift in the importance of transmission from Chinese equity markets to those elsewhere in Asia and a

\footnotetext{
${ }^{17}$ The PBOC typically makes such announcements during weekdays after markets are closed or on weekends. We adjust the dating to the next day when asset markets are open.
} 
corresponding decline in U.S. transmission. There is no comparable shift in the transmission of bond interest rates from either the U.S. or China.

\subsection{Exchange rate linkages}

In this subsection we examine the possible role of exchange rate policies on asset market linkages in Asia. Interest parity theory implies that nominal interest rate correlations should depend on expected exchange rate changes. For example, in the extreme case of a credible fixed exchange rate regime with open capital markets cross-country differences in (nominal) interest rates will be limited by arbitrage. With more exchange rate flexibility between national currencies there is greater room for interest rate differences

We approach this issue by estimating exchange rate sensitivity equations a la Frankel and Wei (1994) by regressing the percent change of the national currency price of Swiss franc (NC/SF) for each Asia country against changes in the SF value of the US dollar (US\$/SF) and rmb (RMB/SF). Higher coefficient values indicate greater sensitivity of national currency value to that of the dollar or rmb. The results are reported in Table 7. Higher coefficients on the China RMB / SF exchange rate variable indicate that a country’s currency is more closely tied to the Chinese exchange rate, i.e. it follows China’s exchange market more closely either by explicit exchange rate policy choice or by market force pressures.

Observe that for the full sample the sensitivity to the rmb is greater than that against the

dollar for all countries. Examining the results for sub-periods, we observe that in pre-GFC period the sensitivity to the dollar was greater for Indonesia, Malaysia, the Philippines, and India. In the GFC and post-GFC periods, the sensitivity to the rmb rose and exceeds that to the dollar for all countries (with the exception of Korea during the GFC), with the latter effects generally insignificant during the GFC. Observe also there is substantial variation across countries in their 
currency linkages with China, with coefficients ranging from .30 for Korea to 1.52 for Indonesia during the GFC, and from .53 for Singapore to 1.41 for India in the post-GFC period.

Figures 7 and 8 combine the evidence reported on the role of exchange rate policy differences across countries (Table 7) with evidence on asset market linkages for subperiods (Appendix Tables A3 and A4). In these figures we compare the estimated rmb sensitivity coefficients with the estimated effects of China asset returns on country bond rates and equity returns reported in the two appendix tables for individual sub-periods. We separate countries into two groups - those below and those above the median exchange rate response in each subperiod (as reported Table 7)-- and compare the average asset rate response coefficient (as reported in Appendix Tables A3 and A4) for each group.

The results are depicted in Figure 7 which shows that countries with greater sensitivity to the rmb are characterized by much stronger linkages to China's bond markets in the GFC and post-GFC periods. That is, countries with strong exchange rate linkages with China also have much stronger interest rate ties, i.e. a given interest rate change in China transmits more strongly because the exchange rates also move in tandem. This may be interpreted as a reflection of interest rate parity arbitrage.

The role of exchange rate policy in equity returns is less clear. As shown in Figure 8, during the GFC equity markets in countries with greater rmb sensitivity exhibit only a marginally greater response to China equity rates than countries with lower rmb sensitivity. Moreover, during the post-GFC period, the relation is reversed. That is, there is no systematic relationship between in equity market linkages and the extent to which the exchange rate is linked to China. One possible explanation is that because individual equity assets are more heterogeneous than 
government bond instruments, international parity conditions are not likely to exert the same influences on national stock market prices as they do on bond rates.

\section{Conclusion}

This paper evaluates how changes in China's financial system, liberalization of capital controls, and the process of financial "internationalization" have affected financial markets in other Asian economies. In particular, we examine how financial market changes in China's economy—-whether driven by policy changes, market-driven developments, institutional changes, or the growing importance in the region—have influenced financial asset prices of its Asian neighbors.

Our main conclusion is that domestic financial development in China as of late 2012 has been modest and internationalization of the currency as well as liberalization of capital controls has been very limited. Consequently, substantial divergences remain between interest rates in China and its neighbors. In particular, only weak linkages were detected in longer-term interest rates (five-year government bond rates). Much stronger linkages appear across equity markets. We argue that equity market arbitrage working through capital markets was not the force driving these linkages between China and Asia. Rather, the emergence of China as the clear regional economic power and the size and dynamism of its economic activity and trading relationships have played the dominant role in linking equity markets across the region.

But why the sudden shift at the time of the global financial crisis in the absence of any substantial and discrete liberalization measures? The crisis caused disruptions in traditional financial linkages and may have increased investors' awareness or "attentiveness" to China as an source and destination of equity finance, partly because of substantial trade linkages, foreign 
direct investment flows, and interconnections in business relationships. Theory and empirical evidence suggests that once investor “inattentiveness” turns to "attentiveness," this is not likely to dissipate soon. This is a plausible explanation for why the sharp increase in equity market linkages between China and Asia since the GFC has persisted.

Moreover, we find that the strength of the transmission of equity prices changes from China across Asia increased markedly during the GFC and has remained relatively high in recent years. By contrast, the strength of equity price linkages between the U.S. and Asia economies decreased during the GFC and remains lower at present. Market forces and rising global uncertainty, rather than policy changes, appear to have increased the importance of China in transmitting equity price changes abroad. 


\section{References}

Allen, William T. and Shen Han (2011). “Assessing China’s Top-Down Securities Markets,” NBER Working paper 16713.

Asian Development Bank (2012). Asian Bond Market Monitor, Sept.

Balasubramaniam, Vimal, Ila Patnaik, and Ajay Shah (2011). "Who Cries about the Chinese Yuan?” National Institute of Public Finance and Policy, New Delhi, Working Paper 2011-89, May.

Baharumshaha, Ahmad Zubaidi, Chan Tze Hawb, A. Mansur M. Masihc, and Evan Laud (2011). "Financial Integration of East Asian Economies: Evidence from Real Interest Parity," Applied Economics 10:16, 1979-1990.

Cheung, Yin-Wong, Menzie Chinn, and Eiji Fuji (2005). "Dimensions of Financial Integration in Greater China: Money Markets, Banks, and Policy Effects,” International Journal of Finance and Economics 10, 117-132.

Cheung, Yin-Wong, Dickson C. Tam, and Matthew S. Yiu (2008). "Does the Chinese Interest Rate Follow the U.S. Interest Rate?” International Journal of Finance and Economics, 13:1, 5367.Frankel, Jeffrey. (2009). "New Estimation of China's Exchange Rate Regime," Pacific Economic Review, 14:3, 346-360.

Frankel, Jeffrey and Shang-Jin Wei (1994). "Yen Bloc or Dollar Bloc? Exchange Rate Policies of the East Asian Countries," in Takatoshi Ito and Anne Krueger (eds.) Macroeconomic Linkage: Savings, Exchange Rates, and Capital Flows, University of Chicago Press.

Fungáčová, Zuzana and Iikka Korhonen (2011). "Like China, the Chinese Banking Sector is in a Class of its Own,” Bank of Finland BOFIT Discussion Papers 32/2011.

Glick, Reuven and Michael Hutchison (1990). AFinancial Liberalization in the Pacific Basin: Implications for Real Interest Rate Linkages,” Journal of the Japanese and International Economies, March.

Glick, Reuven and Michael Hutchison (2009). "Navigating the Trilemma: Capital Flows and Monetary Policy in China,” Journal of Asian Economics 20:3 (May), 205-224.

Huyghebaert, Nancy and Lihong Wang (2010). “The Co-Movement of Stock Markets In East Asia: Did the 1997-1998 Asian Financial Crisis Really Strengthen Stock Market Integration?” China Economic Review 21:1 (March), 98-112.

Hutchison, Michael, Gurnain Kaur Pasricha, and Nirvikar Singh (2012). "Effectiveness of Capital Controls in India: Evidence from the Offshore NDF Market,” IMF Economic Review 60, 395-438. 
Jang, Hong Bum (2011). "Financial Integration and Cooperation in East Asia: Assessment of Recent Developments and Their Implications,” Bank of Japan IMES Discussion Paper No. 2011E-5.

Lee, Hyun-Hoon, Hyeon-seung Huh, and Donghyun Park (2011). "Financial Integration in East Asia: An Empirical Investigation,” ADB Economics Working Paper Series No. 259 (May).

Li, Hong (2012). “The Ipact of China's Stock Market Rreforms on its International Stock market Lnkages.” The Quarterly Review of Economics and Finance 52:4 ( November), 358-368

Ma, Guanan and Robert McCauley (2007). “Do China’s Capital Controls Still Bind? Implications for Monetary Autonomy and Capital Liberalization,” BIS Working Paper No. 233.

Ma, Guonan and Robert McCauley (2010). “The Evolving Renminbi Regime and Implications for Asian Currency Stability,” BIS Working Papers No 32.

Ma, Guonan, Yan Xiandong, and Liu Xi (2011). “China’s Evolving Reserve Requirements,” BOFIT Discussion Papers No. 30, Bank of Finland Institute for Economies in Transition.

Mallaby, S. and O. Wethington (2012). “The Future of the Yuan,” Foreign Affairs, 91(1), 135146.

McCauley, Robert. (2011). "Renminbi Internationalisation and China's Financial Development," Bank for International Settlements Quarterly Review (December), 41-56.

Mondria, Jordi, Thomas Wu and Yi Zhang (2010). “The Determinants of International Investment and Attention Allocation: Using Internet Search Query Data,” Journal of International Economics 82:1 (September), 85-95.

Mondria, Jordi, and Thomas Wu (2011). “Imperfect Financial Integration and Asymmetric Information: Competing Explanations of the Home Bias Puzzle?” forthcoming in Canadian Journal of Economics.

Otani, Ichiro, Tomoyuki Fukumoto, and Yosuke Tsuyuguchi (2011). “China’s Capital Controls and Interest Rate Parity: Experience during 1999 - 2010 and Future Agenda for Reforms,” Bank of Japan Working Paper No.11-E-8, August.

Prasad, Eswar, and Shang-Jin Wei (2007). “China’s Approach to Capital Inflows: Patterns and Possible Explanations,” in Sebastian Edwards (ed,) Capital Controls and Capital Flows in Emerging Economies: Policies, Practices, and Consequences, University of Chicago Press for National Bureau of Economic Research.

Prasad, Eswar and Lei Ye (2012). “The Renminbi’s Role in the Global Monetary System,” in R. Glick and M.M. Spiegel (eds.), Asia's Role in the Post-Crisis Global Economy, Federal Reserve Bank of San Francisco. 


\section{Table 1}

Correlations of daily bond rate changes and equity returns

\begin{tabular}{|c|c|c|c|c|c|c|c|c|c|}
\hline & Indonesia & Korea & Malaysia & Philippines & Singapore & Taiwan & Thailand & India & China \\
\hline \multicolumn{10}{|c|}{ Panel $\mathrm{A}$. Bond rate changes } \\
\hline \multicolumn{10}{|l|}{ Full sample } \\
\hline US & $-0.070 * * *$ & $0.230 * * *$ & $0.191 * * *$ & $-0.070 * * *$ & $0.294 * * *$ & $0.210 * * *$ & $0.163 * * *$ & $0.123^{* * *}$ & -0.015 \\
\hline China & $0.083^{* * *}$ & $0.083^{* * *}$ & 0.022 & 0.027 & -0.023 & $0.043^{*}$ & 0.001 & 0.035 & \\
\hline \multicolumn{10}{|l|}{ Pre-GFC period } \\
\hline US & -0.045 & $0.265^{* * *}$ & $0.162 * * *$ & -0.005 & $0.318^{* * *}$ & $0.249 * * *$ & $0.099 * *$ & $0.116^{* * *}$ & 0.004 \\
\hline China & 0.041 & 0.016 & 0.003 & 0.004 & 0.022 & $0.079 *$ & 0.029 & 0.021 & \\
\hline \multicolumn{10}{|l|}{ GFC period } \\
\hline US & $-0.113^{* *}$ & $0.236 * * *$ & $0.222 * * *$ & $-0.170 * * *$ & $0.257 * * *$ & $0.130 * * *$ & $0.202 * * *$ & $0.128^{* * *}$ & -0.027 \\
\hline China & $0.132^{* * *}$ & $0.116^{* *}$ & 0.015 & 0.059 & $-0.132 * * *$ & 0.011 & -0.011 & 0.046 & \\
\hline \multicolumn{10}{|c|}{ Post-GFC period } \\
\hline US & 0.030 & $0.157^{* * *}$ & $0.178 * * *$ & -0.020 & $0.322 * * *$ & $0.360 * * *$ & $0.202 * * *$ & $0.146^{* * *}$ & -0.026 \\
\hline China & 0.018 & $0.126 * * *$ & 0.067 & 0.015 & 0.051 & 0.01 & -0.033 & 0.043 & \\
\hline
\end{tabular}

Panel B. Equity returns

Full sample

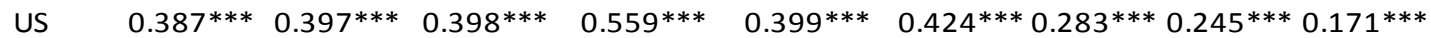

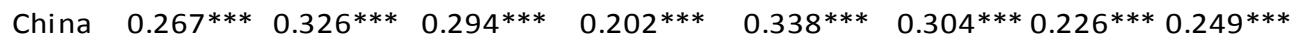

Pre-GFC period

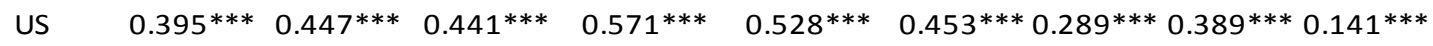

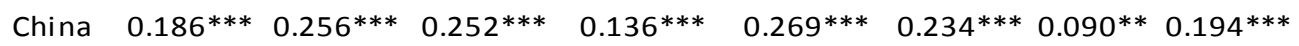

GFC period

US $\quad 0.380^{* * *} \quad 0.347^{* * *} \quad 0.399^{* * *} \quad 0.632^{* * *} \quad 0.338^{* * *} \quad 0.411^{* * *} 0.262 * * * 0.188^{* * *} 0.194 * * *$

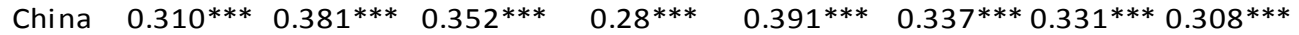

Post-GFC period

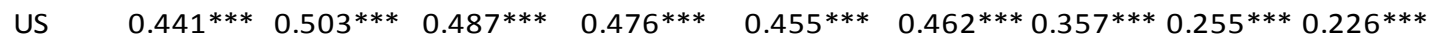

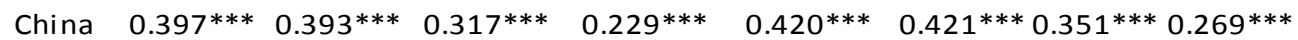

Notes: Bond rates expressed as first differences in percentage points; equity prices as logged first differences.

$*, * *, * *$ denote significance at the $10 \%, 5 \%$, and $1 \%$ levels respectively. 
Table 2

Bond rate and equity return regressions, full sample

Indonesia Korea Malaysia Philippines Singapore Taiwan Thailand India Pooled

Panel A. Bond rate changes

US rate only

$-.183^{*} \quad .195 * * * \quad .090 * * *$

$.195^{* * *} \quad .090^{* * *} \quad-.127^{* *}$

.004

$\begin{array}{lll}(.027) \quad(.016) \quad(.051) & 0\end{array}$

$.170^{* * *}$

$.087^{* * *} .133^{* * *} .106 * * *$

.057

Adj. R2

$.052 \quad .035 \quad .004$

$\begin{array}{lllll}(.018) & (.013) & (.026) & (.025) & (.050)\end{array}$

Nobs

1729

$1686 \quad 1604 \quad 1656$

.085

$\begin{array}{llll}.043 & .025 & .014 & .001\end{array}$

China rate only

China bond $\mathrm{t}$

$.401 * * \quad .130 * * \quad .020 \quad .093$

$\begin{array}{llll}(.202) & (.057) \quad(.027) \quad(.076)\end{array}$

1724

$1484 \quad 1581$

$1584 \quad 13048$

Adj. R2

.006

$006--00$

(.076)

$-.024$

$\begin{array}{llll}.032 & .001 & .061 & .091 *\end{array}$

Nobs

1638

1647

1544

1577

$\begin{array}{llllll}(.030) & (.022) & (.045) & (.046) & (.049)\end{array}$

US and China rate

US bond $\mathrm{t}-1$

$-.207 * \quad .183^{* * *} \quad .084 * * * \quad-.136 * *$

$-.00$

$.001--.00$

$\begin{array}{lllll}1651 & 1452 & 1501 & 1503 & 12513\end{array}$

$(.107) \quad(.027) \quad(.017)$
0

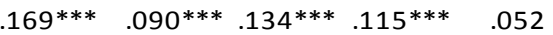

$\begin{array}{lllll}(.021) & (.013) & (.028) & (.026) & (.052)\end{array}$

China bond $\mathrm{t}$

$\begin{array}{llll}(.211) & (.061) & (.027) & (.079)\end{array}$

.081

$-.010$

$\begin{array}{llll}.035 & .003 & .037 & .089 *\end{array}$

(.027)

$\begin{array}{llll}(.021) & (.046) & (.043) & (.047)\end{array}$

Adj. R2

.051

1459

.004

.080

$.046 \quad .023$

Nobs

$\begin{array}{llll}1550 & 1556 & 1459 & 1497\end{array}$

$\begin{array}{lllll}1564 & 1374 & 1417 & 1424 & 11841\end{array}$

Panel B. Equity returns

US return only

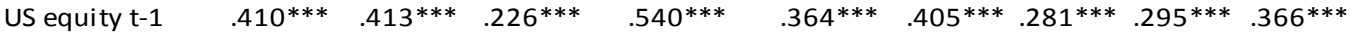

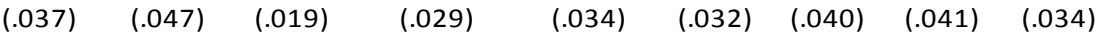

$\begin{array}{llllllllll}\text { Adj. R2 } & .149 & .157 & .158 & .311 & .158 & .179 & .079 & .059 & .140\end{array}$

$\begin{array}{llllllllll}\text { Nobs } & 1656 & 1695 & 1677 & 1652 & 1726 & 1693 & 1642 & 1691 & 13432\end{array}$

China return only

$\begin{array}{cccccccccc}\text { China equity } \mathrm{t} & .230^{* * *} & .274 * * * & .137^{* * *} & .155^{* * *} & .245^{* * *} & .232^{* * *} & .178^{* * *} & .241^{* * *} & .212^{* * *} \\ & (.027) & (.025) & (.015) & (.028) & (.022) & (.023) & (.026) & (.026) & (.017)\end{array}$

$\begin{array}{lllllllllll}\text { Adj. R2 } & .070 & .105 & .086 & .040 & .113 & .091 & .050 & .061 & .073\end{array}$

$\begin{array}{llllllllll}\text { Nobs } & 1610 & 1697 & 1654 & 1610 & 1693 & 1708 & 1609 & 1649 & 13230\end{array}$

US and China return

US equity $\mathrm{t}-1 \quad .374^{* * *} \quad .377^{* * *} \quad .203^{* * *} \quad .534^{* * *}$

$.311^{* * *} \quad .365^{* * *} \quad .241^{* * *} \quad .252^{* * *} \quad .332^{* * *}$

$\begin{array}{llllllllll}(.037) & (.047) & (.018) & (.028) & (.033) & (.031) & (.041) & (.041) & (.036)\end{array}$

China equity $\mathrm{t} \quad .171^{* * *} \quad .224^{* * *} \quad .108^{* * *} \quad .071^{* * *}$

$.202 * * * \quad .184^{* * *} .150^{* * *} .198 * * * \quad .164 * * *$

$\begin{array}{lllllllll}(.024) & (.024) & (.015) & (.023) & (.021) & (.020) & (.026) & (.027) & (.018)\end{array}$

Adj. R2

$\begin{array}{llll}.187 & .228 & .203 & .328\end{array}$

.222

$\begin{array}{llll}.234 & .107 & .098 & .181\end{array}$

Nobs

$\begin{array}{llll}1524 & 1602 & 1561 & 1527\end{array}$

160

$\begin{array}{llll}1610 & 1517 & 1562 & 12507\end{array}$

Notes: Bond rates are in differences; equity prices are in logged first differences. Constants included, but not reported. Pooled regressions in last column employ fixed effects, with errors clustered by country. Robust standard errors in parentheses. Significance at $1,5,10 \%$ indicated by $* * *, * *, *$. 
Table 3

Bond rate and equity return regressions, with VIX and CDS, full sample

Indonesia Korea Malaysia Philippines Singapore Taiwan Thailand India Pooled

Panel A. Bond rates

with VIX

\begin{tabular}{lccccccccc} 
US bond t-1 & -.070 & $.174 * * *$ & $.095^{* * *}$ & -.020 & $.181^{* * *}$ & $.092^{* * *}$ & $.140^{* * *}$ & $.109 * * *$ & $.087^{* * *}$ \\
& $(.113)$ & $(.029)$ & $(.018)$ & $(.047)$ & $(.023)$ & $(.014)$ & $(.029)$ & $(.028)$ & $(.032)$ \\
China bond $\mathrm{t}$ & $.392^{*}$ & $.136^{* *}$ & .024 & .075 & -.010 & .035 & .003 & .037 & $.089^{*}$ \\
& $(.205)$ & $(.060)$ & $(.027)$ & $(.076)$ & $(.027)$ & $(.021)$ & $(.047)$ & $(.043)$ & $(.047)$ \\
VIX t-1 & $.003^{* * *}$ & -.000 & $.000^{* *}$ & $.003^{* * *}$ & $.000^{*}$ & .000 & .000 & -.000 & .000 \\
& $(.000)$ & $(.000)$ & $(.000)$ & $(.000)$ & $(.000)$ & $(.000)$ & $(.000)$ & $(.000)$ & $(.000)$ \\
Adj. R2 & .027 & .052 & .032 & .026 & .081 & .046 & .023 & .015 & .006 \\
Nobs & 1550 & 1556 & 1459 & 1497 & 1564 & 1374 & 1417 & 1424 & 11841 \\
VIX and CDS & & & & & & & & & \\
US bond t-1 & -.022 & $.172 * * *$ & $.097 * *$ & .009 & & & $.140 * * *$ & $.083^{* *}$ \\
& $(.128)$ & $(.030)$ & $(.018)$ & $(.046)$ & & & $(.030)$ & $(.035)$ \\
China bond t & $.436 *$ & $.132 * *$ & .021 & .068 & & & .006 & $.124 *$ \\
& $(.224)$ & $(.061)$ & $(.028)$ & $(.077)$ & & & $(.047)$ & $(.071)$ \\
VIX t-1 & $.002 *$ & -.000 & $.000 *$ & $.002 * * *$ & & & .000 & $.001 *$ \\
& $(.001)$ & $(.000)$ & $(.000)$ & $(.000)$ & & & $(.000)$ & $(.000)$ \\
CDS i,t & $.009 * *$ & -.000 & .000 & $.004 * *$ & & & .000 & .002 \\
& $(.004)$ & $(.000)$ & $(.000)$ & $(.001)$ & & & $(.000)$ & $(.001)$ \\
Adj. R2 & .073 & .051 & .032 & .040 & & & .022 & .016 \\
Nobs & 1392 & 1465 & 1359 & 1406 & & & 1327 & 6949 \\
\hline
\end{tabular}

Panel B. Equity returns

with VIX

\begin{tabular}{lccccccccc} 
US equity t-1 & $.253^{* * *}$ & $.283^{* * *}$ & $.139^{* * *}$ & $.391^{* * *}$ & $.251^{* * *}$ & $.311^{* * *}$ & $.177^{* *}$ & .103 & $.239 * * *$ \\
& $(.062)$ & $(.073)$ & $(.029)$ & $(.044)$ & $(.054)$ & $(.049)$ & $(.069)$ & $(.067)$ & $(.033)$ \\
China equity t & $.169^{* * *}$ & $.223^{* * *}$ & $.108^{* * *}$ & $.068^{* * *}$ & $.202^{* * *}$ & $.183^{* * *}$ & $.150^{* * *}$ & $.197^{* * *} .163^{* * *}$ \\
& $(.024)$ & $(.024)$ & $(.015)$ & $(.022)$ & $(.021)$ & $(.020)$ & $(.026)$ & $(.026)$ & $(.018)$ \\
VIX t-1 & $-.032^{* * *}$ & $-.025^{* *}$ & $-.017^{* * *}$ & $-.039^{* * *}$ & $-.016^{*}$ & $-.014^{*}$ & $-.017^{*}$ & $-.039^{* * *} .025^{* * *}$ \\
& $(.010)$ & $(.010)$ & $(.005)$ & $(.009)$ & $(.009)$ & $(.008)$ & $(.009)$ & $(.011)$ & $(.003)$ \\
Adj. R2 & .197 & .234 & .212 & .344 & .225 & .235 & .109 & .109 & .188 \\
Nobs & 1524 & 1602 & 1561 & 1527 & 1604 & 1610 & 1517 & 1562 & 12507 \\
VIX and CDS & & & & & & & & & \\
US equity t-1 & $.149^{* * *}$ & $.191^{* * *}$ & $.091^{* * *}$ & $.349^{* * *}$ & & & .107 & $.177^{* * *}$ \\
& $(.055)$ & $(.072)$ & $(.029)$ & $(.045)$ & & & $(.068)$ & $(.046)$ \\
China equity t & $.148^{* * *}$ & $.186^{* * *}$ & $.096^{* * *}$ & $.058^{* *}$ & & & $.136 * *$ & $.126^{* * *}$ \\
& $(.024)$ & $.023)$ & $(.014)$ & $(.023)$ & & & $(.027)$ & $(.022)$ \\
VIX t-1 & $-.026^{* * *}$ & $-.022^{* *}$ & $-.017^{* * *}$ & $-.038^{* * *}$ & & & $-.020^{* *}$ & $-.024 * *$ \\
& $(.009)$ & $(.009)$ & $(.005)$ & $(.009)$ & & & $(.009)$ & $(.003)$ \\
CDS i,t & $-.121^{* * *}$ & $-.091^{* * *}$ & $-.047^{* * *}$ & $-.062^{* * *}$ & & & $-.070^{* * *}$ & $-.078^{* * *}$ \\
& $(.015)$ & $(.020)$ & $(.008)$ & $(.014)$ & & & $(.015)$ & $(.012)$ \\
Adj. R2 & .298 & .306 & .269 & .369 & & & .163 & .258 \\
Nobs & 1353 & 1509 & 1461 & 1436 & & & 1424 & 7183 \\
\hline
\end{tabular}

Notes: See Table 3. VIX and CDS expressed as logged first differences. Singapore, Taiwan, and India omitted

from regressions with CDS because data N/A. 
Table 4

Pooled bond and equity regressions, with time period interactions, full sample

\begin{tabular}{|c|c|c|c|c|c|}
\hline & \multicolumn{2}{|c|}{ Bond rate } & & \multicolumn{2}{|c|}{ Equity return } \\
\hline & $(1)$ & $(2)$ & & $(1)$ & $(2)$ \\
\hline \multirow[t]{2}{*}{ US bond $\mathrm{t}-1$} & $.106^{* * *}$ & $.102 * * *$ & US equity $\mathrm{t}-1$ & $.509 * * *$ & $.471 * * *$ \\
\hline & $(.027)$ & $(.034)$ & & $(.043)$ & $(.032)$ \\
\hline \multirow[t]{2}{*}{ China bond $\mathrm{t}$} & $.032 * *$ & $.032 *$ & China equity $t$ & $.087^{* * *}$ & $.087^{* * *}$ \\
\hline & $(.015)$ & $(.016)$ & & $(.013)$ & $(.013)$ \\
\hline \multirow[t]{2}{*}{ VIX t-1 } & .000 & $.000 * *$ & VIX t-1 & $-.013^{* * *}$ & $-.019 * *$ \\
\hline & $(.000)$ & $(.000)$ & & $(.004)$ & $(.007)$ \\
\hline \multirow[t]{2}{*}{ US bond * DGFC } & -.058 & -.030 & US equity *DGFC & $-.290 * * *$ & $-.261 * * *$ \\
\hline & $(.047)$ & $(.025)$ & & $(.033)$ & $(.037)$ \\
\hline \multirow[t]{2}{*}{ US bond * DpostGFC } & .028 & .004 & US equity * DpostGFC & $-.258 * * *$ & $-.162 * * *$ \\
\hline & $(.038)$ & $(.041)$ & & $(.048)$ & $(.035)$ \\
\hline \multirow[t]{2}{*}{ China bond * DGFC } & .146 & .145 & China equity * DGFC & $.155^{* * *}$ & $.155^{* * *}$ \\
\hline & $(.111)$ & (.109) & & $(.021)$ & $(.021)$ \\
\hline \multirow[t]{2}{*}{ China bond $*$ DpostGFC } & .011 & .003 & China equity $*$ DpostGFC & $.143^{* * *}$ & $.144^{* * *}$ \\
\hline & $(.031)$ & $(.033)$ & & $(.025)$ & $(.025)$ \\
\hline \multirow[t]{2}{*}{ VIX t-1 * DGFC } & & .000 & VIX t-1* DGFC & & .002 \\
\hline & & $(.000)$ & & & $(.008)$ \\
\hline \multirow[t]{2}{*}{ VIX t-1* DpostGFC } & & $-.000 * *$ & VIX t-1* DpostGFC & & $.017 * * *$ \\
\hline & & $(.000)$ & & & $(.006)$ \\
\hline \multirow[t]{2}{*}{ DGFC } & $-.006 * * *$ & $-.006 * * *$ & DGFC & .008 & .008 \\
\hline & $(.001)$ & $(.001)$ & & $(.015)$ & $(.015)$ \\
\hline \multirow[t]{2}{*}{ DpostGFC } & $-.002 * *$ & $-.002 * * *$ & DpostGFC & .008 & .008 \\
\hline & $(.000)$ & $(.000)$ & & (.019) & $(.019)$ \\
\hline Adj. R2 & .008 & .009 & Adj. R2 & .204 & .204 \\
\hline Nobs & 11841 & 11841 & Nobs & 12507 & 12507 \\
\hline
\end{tabular}

Notes: See Table 3. Oil prices and VIX are in log differences. DGFC and DpostGFC are time dummies for GFC period and post-GFC period, respectively. 


\section{Table 5}

Pooled bond regressions, with time interactions and augmented explanatory variables, full sample

\begin{tabular}{|c|c|c|c|}
\hline & (1) & (2) & (3) \\
\hline \multirow[t]{2}{*}{ US bond $\mathrm{t}-1$} & $.103^{* * *}$ & $.115^{* * *}$ & $.106 * * *$ \\
\hline & $(.030)$ & $(.023)$ & $(.027)$ \\
\hline \multirow[t]{2}{*}{ China bond $t$} & $.031^{* *}$ & & $.033^{* *}$ \\
\hline & $(.014)$ & & $(.016)$ \\
\hline \multirow[t]{2}{*}{ US bond $\mathrm{t}-1$ * DGFC } & -.043 & -.063 & -.059 \\
\hline & $(.034)$ & $(.048)$ & $(.047)$ \\
\hline \multirow[t]{2}{*}{ US bond t- $1 *$ DpostGFC } & .039 & .026 & .027 \\
\hline & $(.049)$ & $(.033)$ & $(.037)$ \\
\hline \multirow[t]{2}{*}{ China bond $t$ * DGFC } & .150 & & .143 \\
\hline & $(.116)$ & & $(.108)$ \\
\hline \multirow[t]{2}{*}{ China bond $t *$ DpostGFC } & .013 & & .000 \\
\hline & $(.030)$ & & $(.037)$ \\
\hline \multirow[t]{2}{*}{ VIX t-1 } & $.000 *$ & .000 & $.000^{*}$ \\
\hline & $(.000)$ & $(.000)$ & $(.000)$ \\
\hline \multirow{2}{*}{ Oil prices $\mathrm{t}-1$} & -.001 & & \\
\hline & $(.001)$ & & \\
\hline \multirow[t]{2}{*}{ China RR incr t-1 } & & .003 & \\
\hline & & $(.003)$ & \\
\hline \multirow[t]{2}{*}{ China RR decr $\mathrm{t}-1$} & & -.017 & \\
\hline & & $(.018)$ & \\
\hline \multirow[t]{2}{*}{ US bond $\mathrm{t}-1 * \mathrm{VIX} \mathrm{t-1}$} & & & -.001 \\
\hline & & & $(.002)$ \\
\hline \multirow[t]{2}{*}{ China bond $\mathrm{t} * \mathrm{VIX} \mathrm{t}-1$} & & & -.005 \\
\hline & & & $(.004)$ \\
\hline \multirow[t]{2}{*}{ DGFC } & $-.007 * * *$ & $-.007 * * *$ & $-.006 * * *$ \\
\hline & $(.002)$ & $(.001)$ & $(.001)$ \\
\hline \multirow[t]{2}{*}{ DpostGFC } & $-.002 * *$ & $-.002^{* * *}$ & $-.002 * *$ \\
\hline & $(.000)$ & $(.000)$ & $(.000)$ \\
\hline Adj. R2 & .009 & .007 & .006 \\
\hline Nobs & 11841 & 13048 & 11841 \\
\hline
\end{tabular}

Notes: Bond rates are in differences, oil prices and VIX are in log differences. Pooled regressions estimated with fixed effects and errors clustered by country. Robust standard errors in parenthes. Significance at $1,5,10 \%$ indicated by $* * *, * *, *$. 


\section{Table 6}

Pooled equity regressions, with time interactions and augmented explanatory variables, full sample

\begin{tabular}{|c|c|c|c|}
\hline & (1) & (2) & (3) \\
\hline \multirow[t]{2}{*}{ US equity $\mathrm{t}-1$} & $.510 * * *$ & $.542 * * *$ & $.522 * * *$ \\
\hline & $(.042)$ & $(.043)$ & $(.043)$ \\
\hline \multirow[t]{2}{*}{ China equity $t$} & $.087^{* * *}$ & & $.084 * * *$ \\
\hline & $(.013)$ & & $(.013)$ \\
\hline \multirow[t]{2}{*}{ US equity $\mathrm{t}-1 * \mathrm{DGFC}$} & $-.294 * * *$ & $-.283^{* * *}$ & $-.308 * * *$ \\
\hline & $(.028)$ & $(.035)$ & $(.032)$ \\
\hline \multirow[t]{2}{*}{ US equity t-1 * DpostGFC } & $-.262 * * *$ & $-.224 * * *$ & $-.278 * * *$ \\
\hline & $(.046)$ & $(.052)$ & $(.046)$ \\
\hline \multirow[t]{2}{*}{ China $\mathrm{t} * \mathrm{DGFC}$} & $.155^{* * *}$ & & $.154 * * *$ \\
\hline & $(.022)$ & & $(.021)$ \\
\hline \multirow[t]{2}{*}{ China $\mathrm{t} *$ DpostGFC } & $.143 * * *$ & & $.146 * * *$ \\
\hline & $(.025)$ & & $(.026)$ \\
\hline \multirow[t]{2}{*}{ VIX t-1 } & $-.013 * * *$ & $-.012 * * *$ & $-.011 * * *$ \\
\hline & $(.004)$ & $(.004)$ & $(.004)$ \\
\hline \multirow[t]{2}{*}{ Oil t-1 } & .005 & & \\
\hline & $(.010)$ & & \\
\hline \multirow[t]{2}{*}{ China RR incr t-1 } & & $-.104 * *$ & \\
\hline & & $(.050)$ & \\
\hline \multirow[t]{2}{*}{ China RR decr t-1 } & & .009 & \\
\hline & & $(.114)$ & \\
\hline \multirow[t]{2}{*}{ US equity $\mathrm{t}-1 * \mathrm{VIX} \mathrm{t-1}$} & & & $.003 * * *$ \\
\hline & & & $(.000)$ \\
\hline \multirow[t]{2}{*}{ China equity $t * \mathrm{VIX} t-1$} & & & $.004 * * *$ \\
\hline & & & $(.000)$ \\
\hline \multirow[t]{2}{*}{ GFC } & .010 & -.018 & $.038 * * *$ \\
\hline & $(.017)$ & $(.016)$ & $(.014)$ \\
\hline \multirow[t]{2}{*}{ DpostGFC } & .009 & -.024 & .017 \\
\hline & $(.020)$ & (.019) & (.019) \\
\hline Adj. R2 & .204 & .156 & .208 \\
\hline Nobs & 12507 & 13432 & 12507 \\
\hline
\end{tabular}

Notes: Equity prices, oil prices, and VIX are in log differences. Pooled regressions estimated with fixed effects and errors clustered by country. Robust standard errors in parentheses. Significance at 1,5 , $10 \%$ indicated by $* * *, * *, *$. 
Table 7

Exchange rate sensivity regressions, by subperiod

\begin{tabular}{|c|c|c|c|c|c|c|c|c|c|}
\hline & Indonesia & Korea & Malaysia & Philippines & Singapore & Taiwan & Thailand & India & Pooled \\
\hline \multicolumn{10}{|l|}{ Full sample } \\
\hline \multirow[t]{2}{*}{ US\$ / SF } & $.360 * * *$ & -.042 & .062 & $.381 * * *$ & .176 & $.239 * * *$ & $.268 * * *$ & .077 & $.190 * * *$ \\
\hline & (.119) & $(.216)$ & $(.184)$ & $(.131)$ & $(.107)$ & $(.058)$ & $(.097)$ & $(.123)$ & $(.053)$ \\
\hline \multirow[t]{2}{*}{ China RMB / SF } & $.580 * * *$ & $.949 * * *$ & $.880 * * *$ & $.541 * * *$ & $.582 * * *$ & $.717 * * *$ & $.639 * * *$ & $.806^{* * *}$ & k.712*** \\
\hline & $(.120)$ & $(.215)$ & $(.184)$ & $(.131)$ & $(.108)$ & $(.058)$ & $(.097)$ & $(.122)$ & $(.054)$ \\
\hline Adj. R2 & .598 & .378 & .778 & .757 & .752 & .877 & .813 & .653 & .655 \\
\hline Nobs & 1887 & 1901 & 1895 & 1889 & 1905 & 1894 & 1905 & 1782 & 15058 \\
\hline \multicolumn{10}{|l|}{ Pre-GFC period } \\
\hline \multirow[t]{2}{*}{ US\$ / SF } & $.741 * * *$ & .144 & $.560 * * *$ & $.724 * * *$ & .323 & $.349 * * *$ & .223 & $.675^{* * *}$ & ${ }^{k} .466^{* * *}$ \\
\hline & $(.097)$ & $(.214)$ & (.179) & $(.125)$ & $(.214)$ & $(.065)$ & $(.175)$ & $(.096)$ & $(.083)$ \\
\hline \multirow[t]{2}{*}{ China RMB / SF } & $.178^{*}$ & $.796 * * *$ & $.377^{* *}$ & .183 & $.469 * *$ & $.600 * * *$ & $.680 * * *$ & $.245^{* *}$ & $.443 * * *$ \\
\hline & $(.097)$ & $(.210)$ & $(.180)$ & $(.125)$ & $(.216)$ & $(.064)$ & $(.173)$ & $(.095)$ & $(.083)$ \\
\hline Adj. R2 & .533 & .620 & .795 & .679 & .812 & .830 & .643 & .765 & .690 \\
\hline Nobs & 784 & 793 & 787 & 787 & 797 & 786 & 797 & 778 & 6309 \\
\hline \multicolumn{10}{|l|}{ GFC period } \\
\hline \multirow[t]{2}{*}{ US\$ / SF } & -.598 & .517 & -.294 & .281 & $-.437^{*}$ & .009 & .256 & -.357 & -.076 \\
\hline & $(.571)$ & (1.24) & $(.275)$ & $(.356)$ & $(.259)$ & (.198) & $(.192)$ & $(.360)$ & $(.142)$ \\
\hline \multirow[t]{2}{*}{ China RMB / SF } & $1.52 * * *$ & .300 & $1.22 * * *$ & $.631 *$ & $1.13^{* * *}$ & $.924 * * *$ & $.666^{* * *}$ & $1.18^{* * *}$ & k. $947 * * *$ \\
\hline & $(.578)$ & (1.25) & $(.276)$ & $(.358)$ & $(.262)$ & $(.200)$ & $(.191)$ & $(.359)$ & $(.140)$ \\
\hline Adj. R2 & .468 & .173 & .735 & .728 & .731 & .863 & .910 & .550 & .515 \\
\hline Nobs & 496 & 501 & 501 & 497 & 501 & 501 & 501 & 446 & 3944 \\
\hline \multicolumn{10}{|l|}{ Post-GFC period } \\
\hline \multirow[t]{2}{*}{ US\$ / SF } & $.233^{*}$ & -.386 & $-.395 * *$ & .023 & $.259 *$ & $.198^{*}$ & $.317^{* * *}$ & $-.509 * * *$ & $*-.027$ \\
\hline & $(.130)$ & $(.254)$ & $(.166)$ & $(.137)$ & $(.136)$ & $(.110)$ & $(.085)$ & $(.193)$ & (.119) \\
\hline \multirow[t]{2}{*}{ China RMB / SF } & $.733^{* * *}$ & $1.34 * * *$ & $1.35^{* * *}$ & $.916 * * *$ & $.530 * * *$ & $.782 * * *$ & $.581 * * *$ & $1.41 * * *$ & k. $952 * * *$ \\
\hline & $(.130)$ & $(.255)$ & $(.166)$ & $(.138)$ & $(.140)$ & $(.110)$ & $(.081)$ & (.190) & $(.127)$ \\
\hline Adj. R2 & .832 & .682 & .812 & .842 & .739 & .918 & .880 & .686 & .790 \\
\hline Nobs & 607 & 607 & 607 & 605 & 607 & 607 & 607 & 558 & 4805 \\
\hline
\end{tabular}

Notes: Table reports regressions of percent change of national currency price of Swiss franc (NC/SF) against changes in the SF value of US dollar (US\$/SF) and rmb (RMB/SF), with unreported constants. Higher coefficient values indicate greater sensitivity of national currency value to that of the dollar or rmb. Robust standard errors in parentheses. Significance at $1,5,10 \%$ indicated by $* * *, * * *$. 


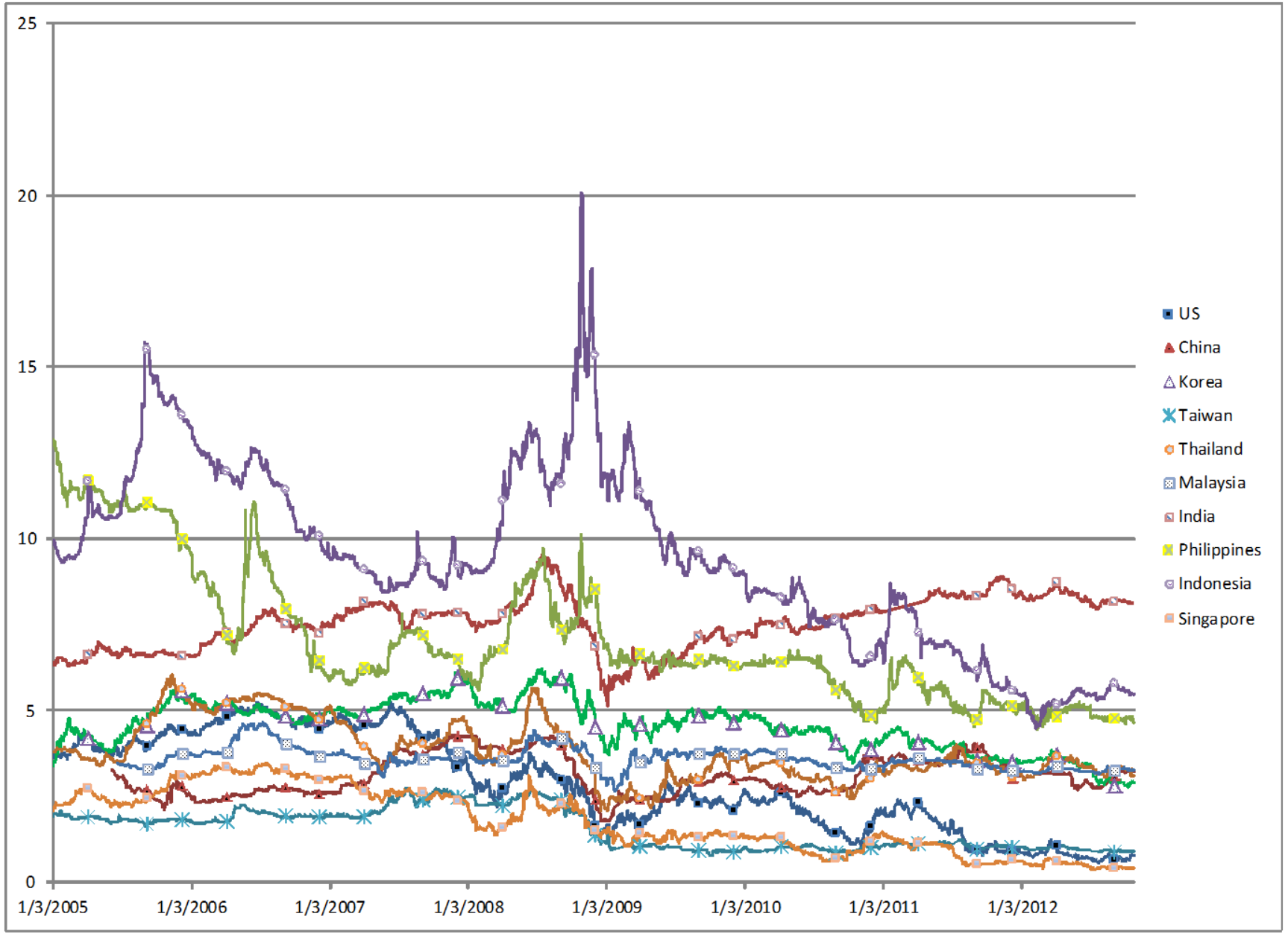

Figure 1. Government bond rates, Asia and the United States (percent) 


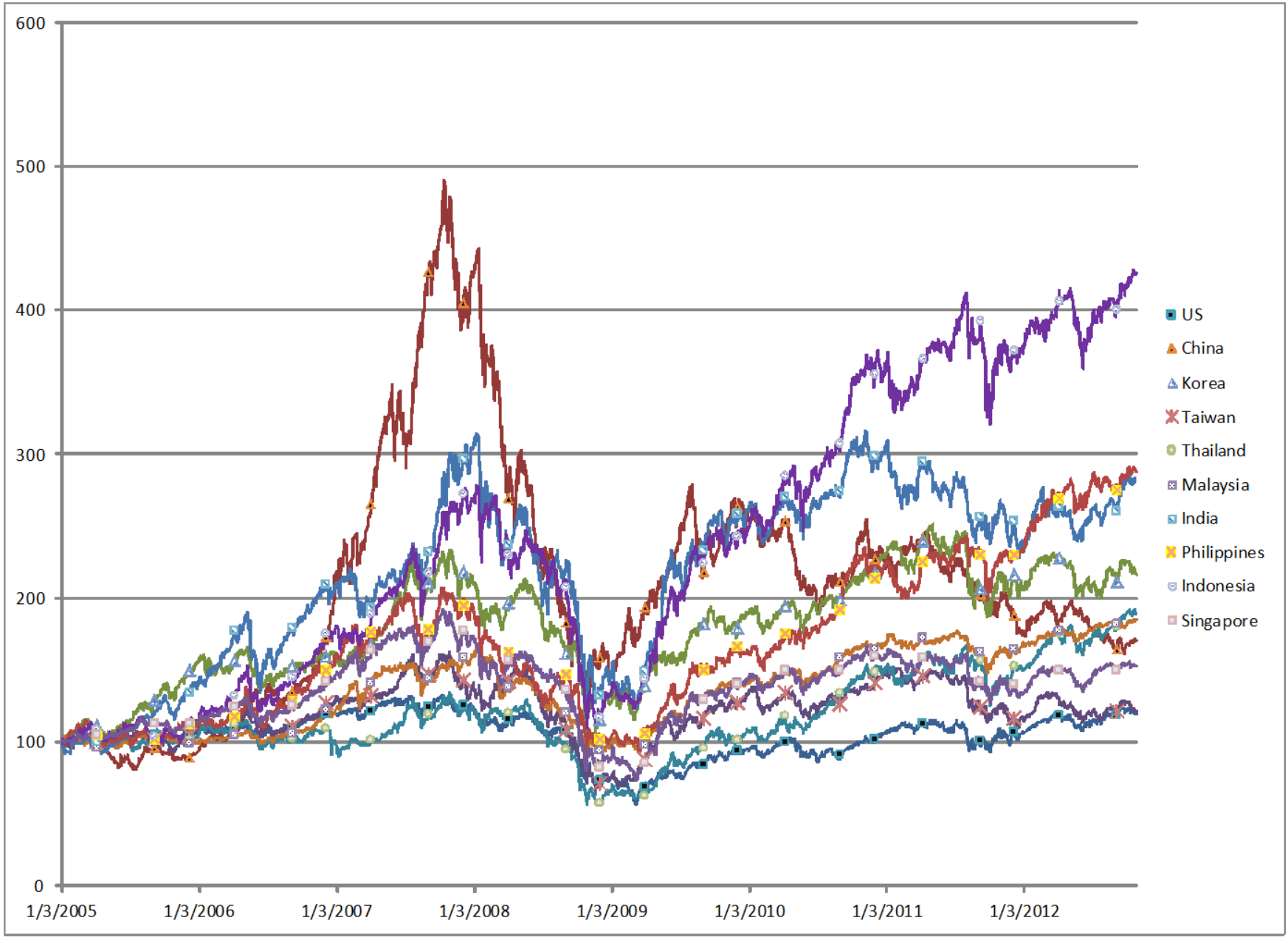

Figure 2. Equity prices, Asia and the United States $(1 / 4 / 2005=100)$ 


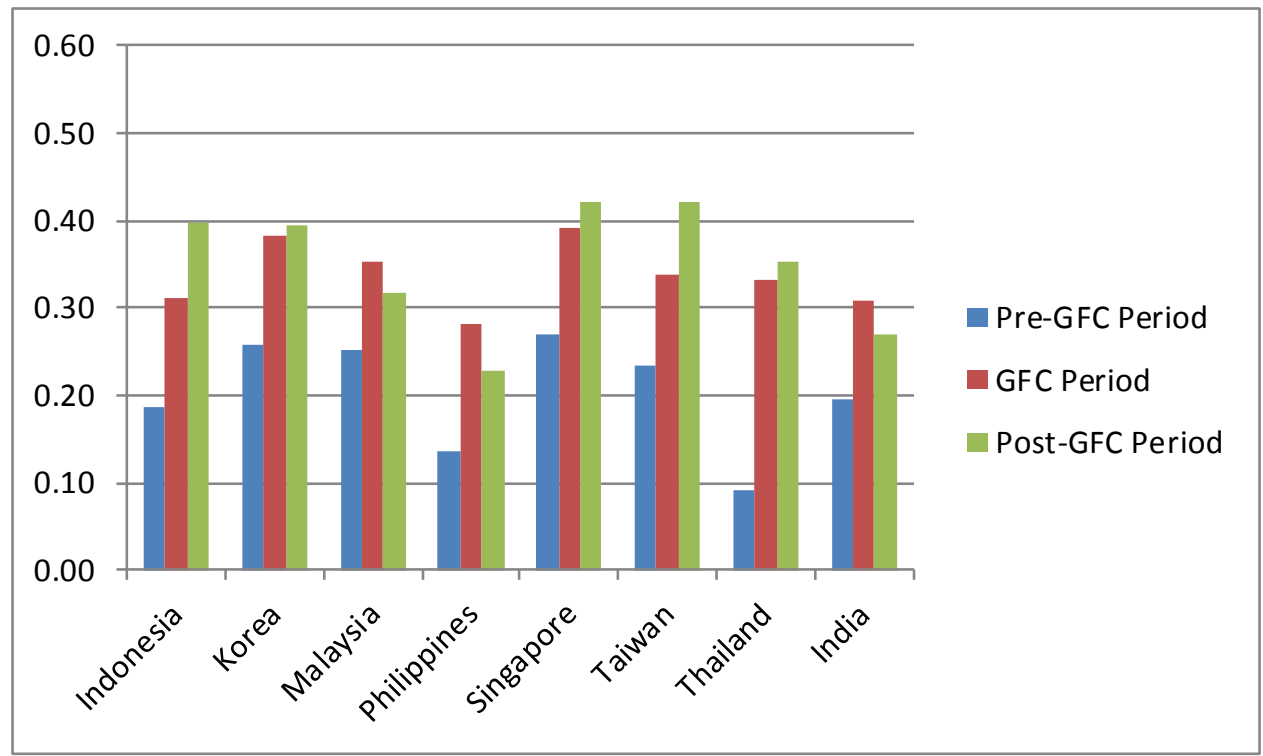

Figure 3. Correlation of Asian country equity returns with China

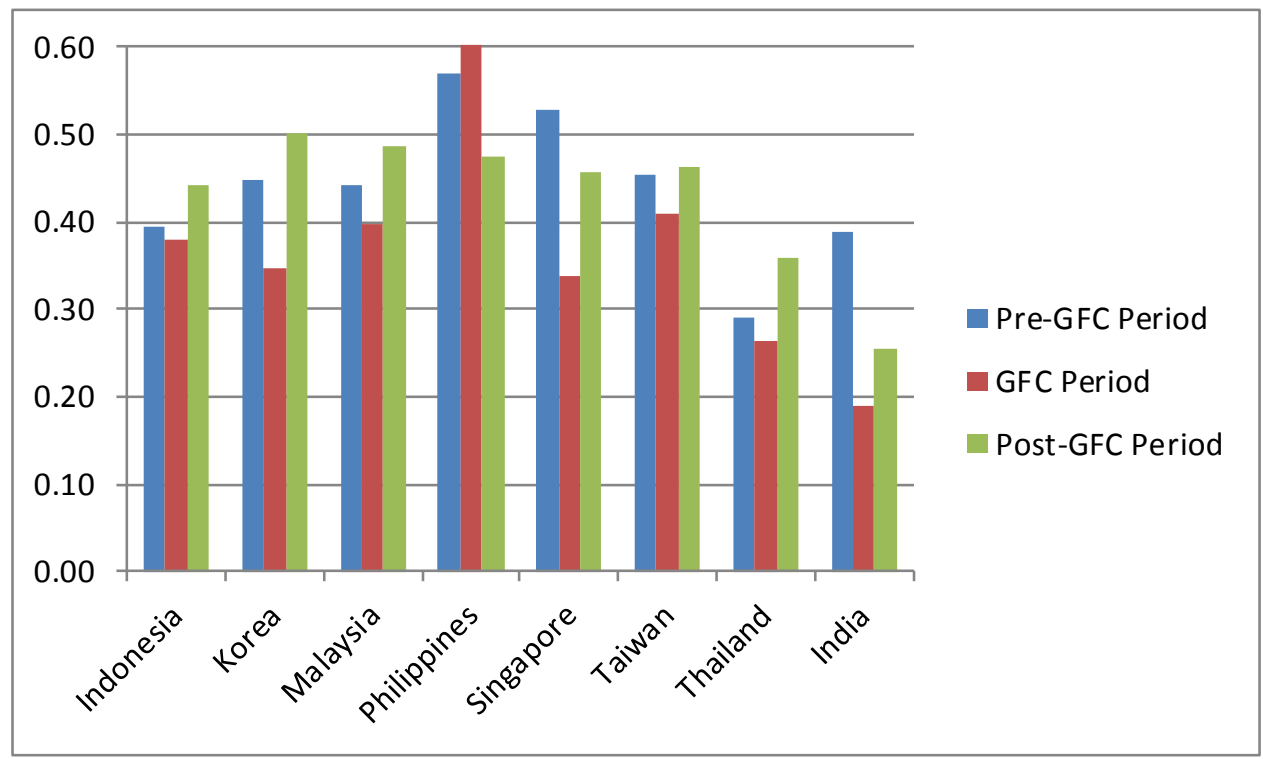

Figure 4. Correlation of Asian country equity returns with the United States 


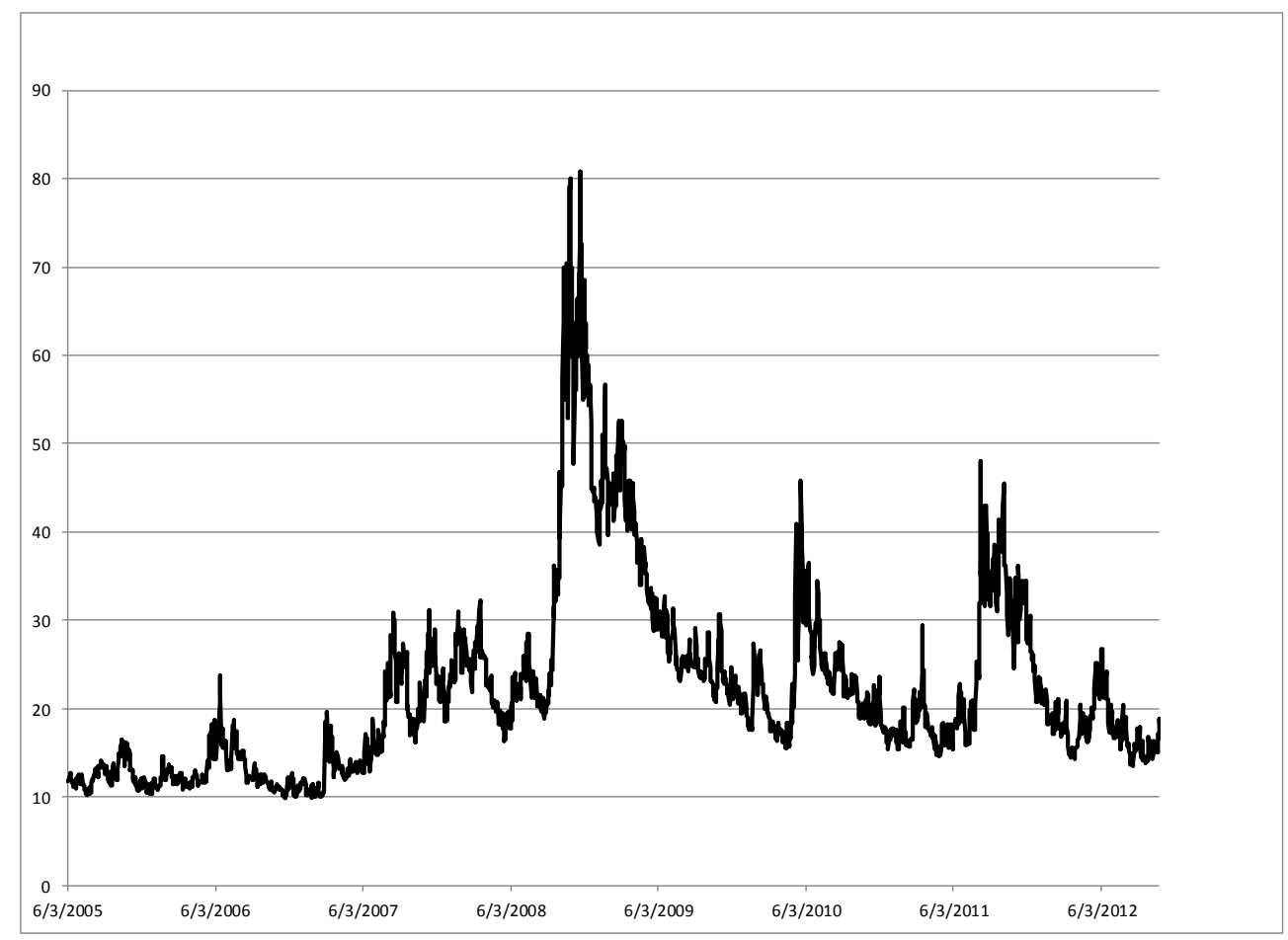

Figure 5. VIX rate (in percentage points)

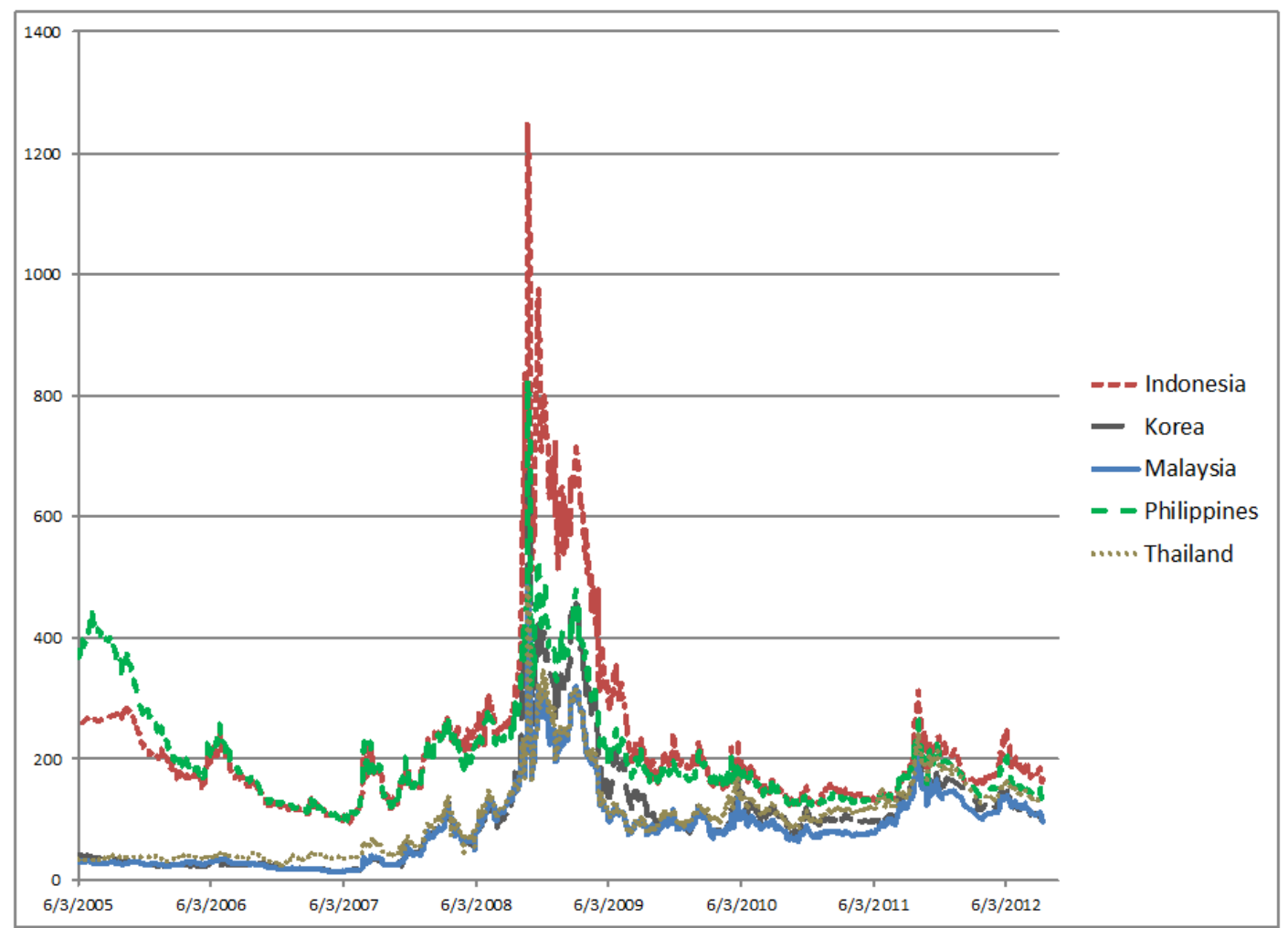

Figure 6. CDS rate (in basis points) 


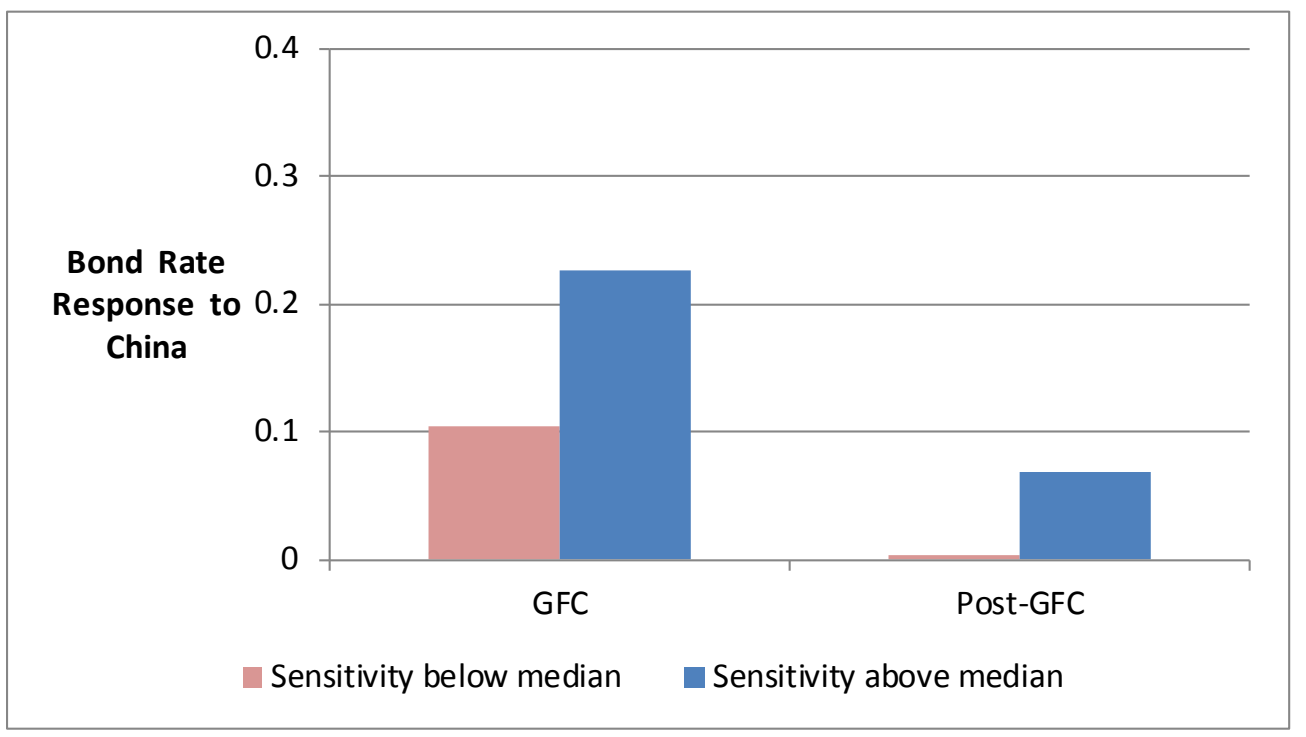

Figure 7. Asia-China bond linkages and exchange rate sensitivity.

Note: The chart reports average Asian bond rate response coefficient for the China bond rate in Appendix Table A3, with countries grouped by the relative sensitivity of their currency to the rmb. Higher sensitivity implies country's currency is more sensitive to changes in the value of rmb.

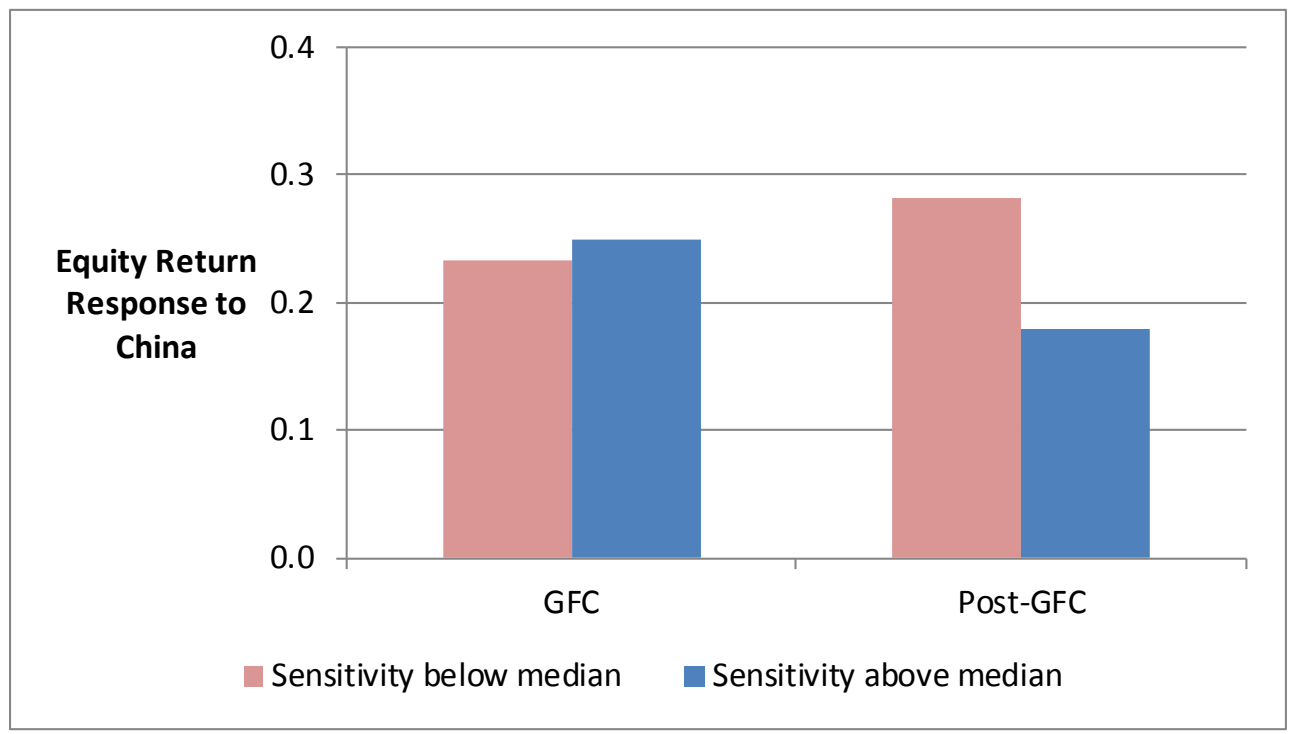

Figure 8. Asia-China equity linkages and exchange rate sensitivity.

Note: The chart reports the average Asian equity return response coefficient to the China bond rate in Appendix Table A4, with countries grouped by the relative sensitivity of their currencies to the rmb. Higher sensitivity implies country's currency is more sensitive to changes in value of rmb. 
Appendix Table A1

Unit Root tests

Indonesia Korea Malaysia Philippines SingaporeTaiwan Thailand India US China

Panel A. Bond rates

ADF stat for level

$\begin{array}{llllllllll}-0.33 & -1.60 & -2.91 & -1.97 & -0.55 & -1.50 & -1.33 & -2.63 & -0.43 & -1.01 \\ (0.92) & (0.48) & (0.04) & (0.30) & (0.88) & (0.53) & (0.62) & (0.09) & (0.90) & (0.75) \\ -23.43 & -23.21 & -19.66 & -19.96 & -24.77 & -20.87 & -19.40 & -19.47 & -27.24 & -20.75 \\ (0.00) & (0.00) & (0.00) & (0.00) & (0.00) & (0.00) & (0.00) & (0.00) & (0.00) & (0.00)\end{array}$

ADF stat. for difference

$(0.00) \quad(0.00) \quad(0.00) \quad(0.00)$

$(0.00)$

$(0.00)$

$\begin{array}{llllll}-0.56 & -1.88 & -0.07 & -1.70 & -1.37 & -1.81\end{array}$

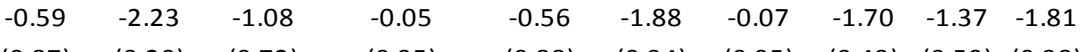

$\begin{array}{llllllllll}(0.87) & (0.20) & (0.72) & (0.95) & (0.88) & (0.34) & (0.95) & (0.43) & (0.59) & (0.38)\end{array}$

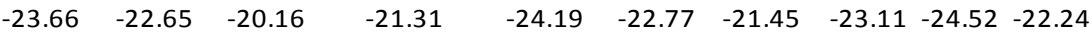

ADF stat. for difference

$(0.00) \quad(0.00) \quad(0.00) \quad(0.00)$

$\begin{array}{llllll}(0.00) & (0.00) & (0.00) & (0.00) & (0.00) & (0.00)\end{array}$

Notes: Table reports augmented Dickey-Fuller test statistics and their $p$ values against null of unit root, with two lags of first difference of dependent variable (bond rate level or logged equity price index). Critical values for 1,5 , and $10 \%$ are $3.43,2.86$, and 2.57 , respectively. 


\section{Appendix Table A2}

Granger Causality Tests

\begin{tabular}{|c|c|c|c|c|c|c|c|c|}
\hline & Indonesia & Korea & Malaysia & Philippines & Singapore & Taiwan & Thailand & India \\
\hline \multicolumn{9}{|l|}{ Panel A. Bond rate changes } \\
\hline \multirow[t]{2}{*}{ US --> Country } & 0.65 & 7.51 & 5.13 & 1.86 & 13.36 & 6.27 & 2.95 & 2.54 \\
\hline & $(0.66)$ & $(0.00)$ & $(0.00)$ & $(0.10)$ & $(0.00)$ & $(0.00)$ & $(0.01)$ & $(0.03)$ \\
\hline \multirow[t]{2}{*}{ China --> Country } & 0.91 & 1.84 & 1.02 & 0.09 & 1.71 & 1.56 & 0.72 & 1.73 \\
\hline & $(0.47)$ & $(0.10)$ & $(0.40)$ & (0.99) & $(0.13)$ & $(0.17)$ & $(0.61)$ & $(0.12)$ \\
\hline \multirow[t]{2}{*}{ Country --> Country } & 0.51 & 0.52 & 4.55 & 1.73 & 2.42 & 0.31 & 1.79 & 1.00 \\
\hline & $(0.77)$ & $(0.76)$ & $(0.00)$ & $(0.12)$ & $(0.03)$ & $(0.91)$ & $(0.11)$ & $(0.42)$ \\
\hline \multicolumn{9}{|l|}{ Dependent country: US } \\
\hline \multirow[t]{2}{*}{ US --> US } & 3.81 & 2.86 & 3.17 & 3.71 & 3.08 & 2.19 & 4.03 & 4.01 \\
\hline & $(0.00)$ & $(0.01)$ & $(0.01)$ & $(0.00)$ & $(0.01)$ & $(0.05)$ & $(0.00)$ & $(0.00)$ \\
\hline \multirow[t]{2}{*}{ China --> US } & 0.55 & 0.71 & 0.52 & 0.76 & 1.13 & 0.86 & 0.47 & 0.88 \\
\hline & $(0.74)$ & $(0.61)$ & $(0.76)$ & $(0.58)$ & $(0.34)$ & $(0.51)$ & $(0.80)$ & $(0.49)$ \\
\hline \multirow[t]{2}{*}{ Country --> US } & 2.85 & 1.56 & 1.14 & 1.52 & 0.65 & 0.75 & 0.60 & 1.03 \\
\hline & $(0.01)$ & $(0.17)$ & $(0.34)$ & $(0.18)$ & $(0.66)$ & (0.59) & $(0.70)$ & $(0.40)$ \\
\hline \multicolumn{9}{|l|}{ Dependent country: China } \\
\hline \multirow[t]{2}{*}{ US --> China } & 2.47 & 2.02 & 2.00 & 2.65 & 2.43 & 1.70 & 1.88 & 2.03 \\
\hline & $(0.03)$ & $(0.07)$ & $(0.08)$ & $(0.02)$ & $(0.03)$ & $(0.13)$ & $(0.10)$ & $(0.07)$ \\
\hline \multirow[t]{2}{*}{ China --> China } & 5.92 & 3.73 & 4.21 & 4.62 & 5.72 & 3.86 & 2.49 & 5.18 \\
\hline & $(0.00)$ & $(0.00)$ & $(0.00)$ & $(0.00)$ & $(0.00)$ & $(0.00)$ & $(0.03)$ & $(0.00)$ \\
\hline \multirow[t]{2}{*}{ Country --> China } & 1.19 & 2.03 & 1.14 & 1.96 & 0.93 & 1.05 & 1.02 & 1.21 \\
\hline & $(0.31)$ & $(0.07)$ & $(0.34)$ & $(0.08)$ & $(0.46)$ & $(0.39)$ & $(0.40)$ & $(0.30)$ \\
\hline \multicolumn{9}{|l|}{ Panel B. Equity returns } \\
\hline \multirow{2}{*}{ US --> Country } & 18.03 & 16.87 & 26.08 & 5232 & 17.77 & 22.06 & 10.10 & 8.29 \\
\hline & $(0.00)$ & $(0.00)$ & $(0.00)$ & $(0.00)$ & $(0.00)$ & $(0.00)$ & $(0.00)$ & $(0.00)$ \\
\hline \multirow[t]{2}{*}{ China --> Country } & 2.01 & 1.86 & 2.46 & 1.42 & 1.73 & 0.72 & 0.61 & 3.62 \\
\hline & $(0.08)$ & $(0.10)$ & $(0.03)$ & $(0.21)$ & $(0.13)$ & $(0.61)$ & $(0.70)$ & $(0.00)$ \\
\hline \multirow[t]{2}{*}{ Country --> Country } & 1.44 & 2.68 & 1.37 & 2.08 & 4.17 & 1.58 & 0.98 & 3.52 \\
\hline & $(0.21)$ & $(0.02)$ & $(0.23)$ & (0.07) & $(0.00)$ & $(0.16)$ & $(0.43)$ & $(0.00)$ \\
\hline \multicolumn{9}{|l|}{ Dependent country: US } \\
\hline \multirow[t]{2}{*}{ US --> US } & 1.90 & 1.62 & 1.35 & 1.48 & 1.26 & 1.32 & 1.49 & 2.11 \\
\hline & (0.09) & $(0.15)$ & $(0.24)$ & (0.19) & $(0.28)$ & $(0.25)$ & (0.19) & $(0.06)$ \\
\hline \multirow[t]{2}{*}{ China --> US } & 1.11 & 0.65 & 1.37 & 1.21 & 0.46 & 1.35 & 0.33 & 0.60 \\
\hline & $(0.35)$ & $(0.67)$ & $(0.23)$ & $(0.30)$ & $(0.81)$ & $(0.24)$ & $(0.90)$ & $(0.70)$ \\
\hline \multirow[t]{2}{*}{ Country --> US } & 1.26 & 0.99 & 0.98 & 0.56 & 0.34 & 0.96 & 1.54 & 0.54 \\
\hline & $(0.28)$ & $(0.42)$ & $(0.43)$ & $(0.73)$ & $(0.89)$ & $(0.44)$ & $(0.17)$ & $(0.74)$ \\
\hline \multicolumn{9}{|l|}{ Dependent country: China } \\
\hline \multirow[t]{2}{*}{ US --> China } & 2.24 & 3.86 & 4.20 & 3.97 & 4.61 & 4.00 & 3.87 & 2.28 \\
\hline & $(0.05)$ & $(0.00)$ & $(0.00)$ & $(0.00)$ & $(0.00)$ & $(0.00)$ & $(0.00)$ & $(0.04)$ \\
\hline \multirow[t]{2}{*}{ China --> China } & 0.69 & 0.56 & 0.86 & 0.67 & 1.28 & 0.54 & 1.12 & 1.01 \\
\hline & $(0.63)$ & $(0.73)$ & $(0.51)$ & $(0.65)$ & $(0.27)$ & $(0.74)$ & $(0.35)$ & $(0.41)$ \\
\hline Country --> China & 0.93 & 0.46 & 0.47 & 0.96 & 1.02 & 0.80 & 0.48 & 0.62 \\
\hline & $(0.46)$ & $(0.81)$ & $(0.80)$ & $(0.44)$ & $(0.40)$ & $(0.55)$ & $(0.79)$ & $(0.68)$ \\
\hline
\end{tabular}

other two variables or itself in equations with five lags of each variable. P-values in parentheses 


\section{Appendix Table A3}

Bond rate regressions, by subperiods

Indonesia Korea Malaysia Philippines Singapore Taiwan Thailand India Pooled

\begin{tabular}{|c|c|c|c|c|c|c|c|c|c|}
\hline \multicolumn{10}{|l|}{ Pre-GFC period } \\
\hline US bond t-1 & $\begin{array}{l}-.070 \\
(.107)\end{array}$ & $\begin{array}{c}.216 * * * \\
(.040)\end{array}$ & $\begin{array}{c}.105^{* * *} \\
(.023)\end{array}$ & $\begin{array}{c}.057 \\
(.069)\end{array}$ & $\begin{array}{c}.224^{* * *} \\
(.040)\end{array}$ & $\begin{array}{c}.118^{* * *} \\
(.023)\end{array}$ & $\begin{array}{c}.069 \\
(.046)\end{array}$ & $\begin{array}{c}.095 * * * \\
(.031)\end{array}$ & $\begin{array}{c}.102 * * * \\
(.034)\end{array}$ \\
\hline China bond $t$ & $\begin{array}{c}.141 \\
(.108)\end{array}$ & $\begin{array}{c}.006 \\
(.059)\end{array}$ & $\begin{array}{l}-.010 \\
(.035)\end{array}$ & $\begin{array}{l}-.010 \\
(.090)\end{array}$ & $\begin{array}{c}.013 \\
(.054)\end{array}$ & $\begin{array}{l}.058 * * \\
(.026)\end{array}$ & $\begin{array}{c}.034 \\
(.072)\end{array}$ & $\begin{array}{c}.021 \\
(.040)\end{array}$ & $\begin{array}{l}.032 * * \\
(.016)\end{array}$ \\
\hline VIX t-1 & $\begin{array}{l}.001^{* *} \\
(.000)\end{array}$ & $\begin{array}{c}.000 \\
(.000)\end{array}$ & $\begin{array}{c}.000 * * * \\
(.000)\end{array}$ & $\begin{array}{c}.002 * * * \\
(.000)\end{array}$ & $\begin{array}{c}.000 \\
(.000)\end{array}$ & $\begin{array}{c}.000 \\
(.000)\end{array}$ & $\begin{array}{c}.000 \\
(.000)\end{array}$ & $\begin{array}{c}.000 \\
(.000)\end{array}$ & $\begin{array}{l}.000 * * \\
(.000)\end{array}$ \\
\hline Adj. R2 & .011 & .068 & .039 & .009 & .094 & .059 & .002 & .012 & .008 \\
\hline Nobs & 627 & 638 & 584 & 617 & 647 & 563 & 584 & 617 & 4877 \\
\hline \multicolumn{10}{|l|}{ GFC period } \\
\hline US bond $\mathrm{t}-1$ & $\begin{array}{l}-.130 \\
(.256)\end{array}$ & $\begin{array}{c}.173 * * * \\
(.055)\end{array}$ & $\begin{array}{c}.099 * * * \\
(.035)\end{array}$ & $\begin{array}{l}-.053 \\
(.075)\end{array}$ & $\begin{array}{c}.128 * * * \\
(.032)\end{array}$ & $\begin{array}{c}.067^{* * *} \\
(.024)\end{array}$ & $\begin{array}{c}.173 * * * \\
(.048)\end{array}$ & $\begin{array}{l}.132 * * \\
(.059)\end{array}$ & $\begin{array}{l}.072 * \\
(.040)\end{array}$ \\
\hline China Bond t & $\begin{array}{l}.928 * \\
(.533)\end{array}$ & $\begin{array}{l}.248 * \\
(.135)\end{array}$ & $\begin{array}{c}.033 \\
(.058)\end{array}$ & $\begin{array}{c}.157 \\
(.164)\end{array}$ & $\begin{array}{c}-.091 * * \\
(.040)\end{array}$ & $\begin{array}{c}.014 \\
(.058)\end{array}$ & $\begin{array}{c}.001 \\
(.108)\end{array}$ & $\begin{array}{c}.035 \\
(.128)\end{array}$ & $\begin{array}{c}.177 \\
(.121)\end{array}$ \\
\hline VIX t-1 & $\begin{array}{c}.007 * * * \\
(.002)\end{array}$ & $\begin{array}{l}-.000 \\
(.000)\end{array}$ & $\begin{array}{c}.000 \\
(.000)\end{array}$ & $\begin{array}{c}.005^{* * *} \\
(.001)\end{array}$ & $\begin{array}{c}.000 \\
(.000)\end{array}$ & $\begin{array}{l}-.000 \\
(.000)\end{array}$ & $\begin{array}{c}.000 \\
(.000)\end{array}$ & $\begin{array}{l}-.000 \\
(.000)\end{array}$ & $\begin{array}{c}.001 \\
(.001)\end{array}$ \\
\hline Adj. R2 & .054 & .051 & .027 & .089 & .057 & .015 & .034 & .013 & .009 \\
\hline Nobs & 413 & 424 & 404 & 400 & 419 & 383 & 388 & 390 & 3221 \\
\hline \multicolumn{10}{|l|}{ Post-GFC period } \\
\hline US bond $\mathrm{t}-1$ & $\begin{array}{c}.148 \\
(.092)\end{array}$ & $\begin{array}{l}.093^{* *} \\
(.044)\end{array}$ & $\begin{array}{c}.068 * * * \\
(.024)\end{array}$ & $\begin{array}{l}-.024 \\
(.095)\end{array}$ & $\begin{array}{c}.201 * * * \\
(.045)\end{array}$ & $\begin{array}{c}.090 * * * \\
(.017)\end{array}$ & $\begin{array}{c}.216 * * * \\
(.063)\end{array}$ & $\begin{array}{l}.068^{* *} \\
(.031)\end{array}$ & $\begin{array}{c}.107^{* * *} \\
(.027)\end{array}$ \\
\hline China bond $t$ & $\begin{array}{l}-.000 \\
(.080)\end{array}$ & $\begin{array}{l}.155^{* *} \\
(.074)\end{array}$ & $\begin{array}{c}.040 \\
(.036)\end{array}$ & $\begin{array}{c}.036 \\
(.119)\end{array}$ & $\begin{array}{c}.050 \\
(.037)\end{array}$ & $\begin{array}{c}.011 \\
(.020)\end{array}$ & $\begin{array}{l}-.048 \\
(.040)\end{array}$ & $\begin{array}{c}.040 \\
(.037)\end{array}$ & $\begin{array}{c}.036 \\
(.022)\end{array}$ \\
\hline VIX t-1 & $\begin{array}{c}.002 * * * \\
(.000)\end{array}$ & $\begin{array}{l}-.000 * \\
(.000)\end{array}$ & $\begin{array}{l}-.000 \\
(.000)\end{array}$ & $\begin{array}{l}.001 * * \\
(.000)\end{array}$ & $\begin{array}{c}.000 \\
(.000)\end{array}$ & $\begin{array}{l}-.000 \\
(.000)\end{array}$ & $\begin{array}{c}.000 \\
(.000)\end{array}$ & $\begin{array}{c}-.000 * * \\
(.000)\end{array}$ & $\begin{array}{c}.000 \\
(.000)\end{array}$ \\
\hline Adj. R2 & .024 & .042 & .035 & .004 & .111 & .126 & .039 & .031 & .008 \\
\hline Nobs & 510 & 494 & 471 & 480 & 498 & 428 & 445 & 417 & 3743 \\
\hline
\end{tabular}

Notes: Bond rates are in differences, oil prices and VIX are in log differences. Pooled regressions estimated with fixed effects and errors clustered by country. Robust standard errors in parentheses. Significance at 1,5 , $10 \%$ indicated by ***,**,*. 


\section{Appendix Table A4}

Equity return regressions, by subperiods

\begin{tabular}{|c|c|c|c|c|c|c|c|c|c|}
\hline & Indonesi & Korea & Malaysia & Philippin & s Singapore & Taiwan & Thailand & India & Pooled \\
\hline \multicolumn{10}{|l|}{ Pre-GFC period } \\
\hline \multirow[t]{2}{*}{ US equity t-1 } & $.386 * * *$ & $.480 * * *$ & $.379 * * *$ & $.515^{* * *}$ & $.572 * * *$ & $.617^{* * *}$ & $.373 * * *$ & $.447^{* * *}$ & $.471^{* * *}$ \\
\hline & $(.140)$ & $(.095)$ & $(.095)$ & $(.101)$ & $(.103)$ & $(.099)$ & $(.101)$ & $(.137)$ & $(.032)$ \\
\hline \multirow[t]{2}{*}{ China equity $t$} & $.081 * * *$ & $.131 * * *$ & $.089 * * *$ & .027 & $.112 * * *$ & $.113^{* * *}$ & .037 & $.105^{* * *}$ & $.087^{* * *}$ \\
\hline & $(.031)$ & $(.025)$ & $(.022)$ & $(.024)$ & $(.026)$ & $(.023)$ & $(.026)$ & $(.033)$ & $(.013)$ \\
\hline \multirow[t]{2}{*}{$\mathrm{VIX} \mathrm{t-1}$} & $-.033 *$ & -.017 & -.007 & $-.059 * * *$ & -.009 & .009 & -.002 & $-.035^{*}$ & $-.019 * *$ \\
\hline & $(.017)$ & $(.012)$ & $(.012)$ & $(.016)$ & $(.013)$ & $(.012)$ & $(.013)$ & $(.019)$ & $(.007)$ \\
\hline Adj. R2 & .167 & .232 & .225 & .357 & .298 & .235 & .075 & .162 & .200 \\
\hline Nobs & 640 & 669 & 667 & 643 & 679 & 673 & 641 & 662 & 5274 \\
\hline \multicolumn{10}{|l|}{ GFC period } \\
\hline \multirow[t]{2}{*}{ US equity t-1 } & $.266 * * *$ & $.219 * *$ & $.118^{* * *}$ & $.422 * * *$ & $.245 * * *$ & $.241 * * *$ & .107 & .045 & $.210 * * *$ \\
\hline & $(.092)$ & (.099) & $(.036)$ & $(.056)$ & $(.076)$ & $(.068)$ & $(.095)$ & $(.094)$ & $(.041)$ \\
\hline \multirow[t]{2}{*}{ China equity $t$} & $.238^{* * *}$ & $.315^{* * *}$ & $.131 * * *$ & $.123^{* *}$ & $.304 * * *$ & $.229 * * *$ & $.263 * * *$ & $.323 * * *$ & $.242 * * *$ \\
\hline & $(.048)$ & $(.053)$ & $(.023)$ & $(.048)$ & $(.043)$ & $(.041)$ & $(.057)$ & $(.054)$ & $(.026)$ \\
\hline \multirow[t]{2}{*}{ VIX t-1 } & -.014 & -.020 & -.009 & -.023 & .010 & -.020 & -.027 & -.035 & $-.016 * * *$ \\
\hline & $(.023)$ & $(.020)$ & $(.008)$ & $(.016)$ & $(.018)$ & $(.016)$ & $(.020)$ & $(.023)$ & $(.004)$ \\
\hline Adj. R2 & .210 & .223 & .234 & .434 & .218 & .232 & .148 & .113 & .197 \\
\hline Nobs & 395 & 424 & 408 & 398 & 421 & 426 & 401 & 404 & 3277 \\
\hline \multicolumn{10}{|l|}{ Post-GFC period } \\
\hline \multirow[t]{2}{*}{ US equity t-1 } & $.236 * * *$ & $.521 * * *$ & $.199 * * *$ & $.326 * * *$ & $.295 * * *$ & $.403 * * *$ & $.256 * * *$ & $.222 * * *$ & $.309 * * *$ \\
\hline & $(.083)$ & $(.099)$ & $(.038)$ & $(.070)$ & $(.054)$ & $(.087)$ & $(.076)$ & $(.081)$ & $(.039)$ \\
\hline \multirow[t]{2}{*}{ China equity $t$} & $.311 * * *$ & $.302 * * *$ & $.104 * * *$ & $.102 * * *$ & $.251 * * *$ & $.300 * * *$ & $.262 * * *$ & $.207^{* * *}$ & $.232 * * *$ \\
\hline & $(.048)$ & $(.040)$ & $(.024)$ & $(.039)$ & $(.032)$ & $(.039)$ & $(.041)$ & $(.042)$ & $(.029)$ \\
\hline \multirow[t]{2}{*}{ VIX t-1 } & $-.024 * *$ & .008 & -.000 & -.013 & .002 & .006 & .001 & .005 & -.001 \\
\hline & $(.011)$ & $(.013)$ & $(.005)$ & $(.010)$ & $(.009)$ & $(.012)$ & $(.011)$ & $(.012)$ & $(.004)$ \\
\hline Adj. R2 & .279 & .328 & .254 & .233 & .286 & .306 & .180 & .102 & .231 \\
\hline Nobs & 489 & 509 & 486 & 486 & 504 & 511 & 475 & 496 & 3956 \\
\hline
\end{tabular}

Notes: Equity prices, oil prices, and VIX are in log differences. Pooled regressions estimated with fixed effects and errors clustered by country. Robust standard errors in parentheses. Significance at 1, 5, 10\% indicated by $* * *, * *, *$. 